\title{
Measuring the implementation of ecodesign management practices: a review and consolidation of process-oriented performance indicators
}

\author{
Rodrigues, Vinicius Picanco; Pigosso, Daniela Cristina Antelmi; McAloone, Tim C.
}

Published in:

Journal of Cleaner Production

Link to article, DOI:

10.1016/j.jclepro.2017.04.049

Publication date:

2017

Document Version

Peer reviewed version

Link back to DTU Orbit

Citation (APA):

Rodrigues, V. P., Pigosso, D. C. A., \& McAloone, T. C. (2017). Measuring the implementation of ecodesign management practices: a review and consolidation of process-oriented performance indicators. Journal of Cleaner Production, 156, 293-309. https://doi.org/10.1016/j.jclepro.2017.04.049

\section{General rights}

Copyright and moral rights for the publications made accessible in the public portal are retained by the authors and/or other copyright owners and it is a condition of accessing publications that users recognise and abide by the legal requirements associated with these rights.

- Users may download and print one copy of any publication from the public portal for the purpose of private study or research.

- You may not further distribute the material or use it for any profit-making activity or commercial gain

- You may freely distribute the URL identifying the publication in the public portal 
Word count: 15395

\title{
Measuring the implementation of ecodesign management practices: a review and consolidation of process-oriented performance indicators
}

\author{
Vinícius P. Rodrigues", Daniela C. A. Pigosso, Tim C. McAloone \\ Technical University of Denmark, Department of Mechanical Engineering, Building 426, Produktionstorvet, \\ 2800 Kgs. Lyngby, Denmark \\ * Corresponding author
}

E-mail addresses: vipiro@dtu.dk(Vinicius P.Rodrigues),danpi@dtu.dk(Daniela C.A.Pigosso),tmca@dtu.dk (Tim C. McAloone)

\begin{abstract}
Ecodesign plays an important role in manufacturing companies' quest for improved sustainability performance. However, many ecodesign efforts are geared towards tackling single-issue discrete improvements, in contrast to operationalizing, measuring and acting upon the consistent improvement of ecodesign implementation and management. To enable a systematic and streamlined integration of ecodesign practices into the product development processes, adequate mechanisms are needed to capture and measure performance improvements, and thereby achieve consistent improvements in a company's efforts towards enhanced sustainability performance. In face of this challenge, this paper aims at providing organizations with a set of process-oriented indicators to supporting and enhancing ecodesign implementation and management. This research was grounded on a 2-phase approach to (i) cross-analyze performance indicators from literature against ecodesign practices at the process level and (ii) propose, evaluate and consolidate new indicators. After being subjected to the evaluation of 8 experts in ecodesign, a repository is presented with 27 indicators from literature and a set of 114 newly proposed indicators for companies to customize, adapt, mix and derive according to their needs, strategic drivers and overall context.
\end{abstract}

Keywords: performance measurement, performance indicators, ecodesign implementation, ecodesign management practices, sustainable product development.

\section{Introduction}

To properly tackle the most pressing global sustainable development challenges (United Nations, 2015), a combined and orchestrated effort from multiple actors in society is required. Particularly within this context and centered upon the Brundtland's definition of sustainable development (WCED, 1987), Lozano, Carpenter and Huisingh (2015) emphasize corporate sustainability as a way to manage business that holistically balances the economic, environmental, and social perspectives in the present generation while also considering the impacts on future ones. Within the corporate reach, numerous sustainability initiatives, programs and projects can be implemented in the many different business processes (Lozano, 2012).

Product development processes (PDP) encompasses a set of processes with a high potential of improving a manufacturing company's performance, since it is believed that ca. $80 \%$ of a product's sustainability performance is defined during the early stages of its development (McAloone and Bey, 2009). Ecodesign is one of the sustainability's set of initiatives targeted at improving the way companies develop products from an environmental point of view, and can be formally defined as an approach for the integration of environmental aspects into product development and its related processes (e.g. logistics, manufacturing, supply chain etc.) (Pigosso et al., 2015, 2013). Many aspects of ecodesign and product development in general are closely related to various considerations regarding value chains and supply chains. Therefore, the topic is tightly connected to the broader field known as Sustainable Supply Chain Management (SSCM) (Azevedo et al., 2011; Carter and Rogers, 2008; Dües et al., 2013; Gmelin and Seuring, 2014; Hajmohammad et al., 2013; Seuring and Müller, 2008; Soylu and Dumville, 2011) or Green Supply Chain Management (GSCM) (Hervani et al., 2005; Sarkis, 2003; Zhu et al., 2008). The particular focus on business processes arises from the essential assumption that 
through the continuous improvement of product development processes, products with a superior environmental performance $^{1}$ will naturally be the outcome (Pigosso et al., 2013).

A number of potential business benefits gained by the implementation of ecodesign programs in manufacturing companies have been increasingly reported by literature and corporate actors. These benefits ranges from enhanced innovation potential and exploitation of new business models to the development of new markets and more robust mechanisms for complying with customers and regulatory requirements (Bevilacqua et al., 2007; ISO, 2011; Plouffe et al., 2011). Nevertheless, challenges and barriers for ecodesign implementation are still relevant within the context of manufacturing companies (Boks, 2006; Boks and Stevels, 2007), especially those connected to measuring the reported business benefits of ecodesign. Additionally, since ecodesign implementation has been primarily evaluated in terms of product-related measures (Handfield et al., 2001), e.g. energy, material, physical properties etc. (Issa et al., 2015), performance indicators for measuring the performance (effectiveness and efficacy (Neely, 2005)) of ecodesign implementation from a process-oriented perspective is not fully exploited.

As an example to illustrate the difference between product-oriented and process-oriented performance indicators, consider the indicator "product's total energy consumption" - this is product-specific indicator which focuses on one technical aspect of an individual product, and varies across the company's portfolio of products. As opposed to this product-oriented indicator, a manufacturing company can take a portfolio perspective by defining and measuring, for instance, the "number of products in the portfolio with targets for reduction in energy consumption" or "number of products in the portfolio whose energy performance is enhanced" - those two examples are process-oriented indicators, overlooking the product development process.

Complementarily, the proper systematization of ecodesign practices into the PDP is a major concern for achieving higher levels of ecodesign implementation (Baumann et al., 2002; Pigosso et al., 2013). Therefore, to move from partial and unstructured consideration of ecodesign practices in the product development to a formalized, monitored and controlled approach, companies have to define and use process-oriented indicators to track performance and act on its improvement towards higher maturity levels in ecodesign (Pigosso et al., 2013). This is fundamentally based on the idea that well-defined and managed sustainability-oriented practices help the value creation process in an organization. Therefore, within the scope of the potential benefits generated from the adoption of sustainability practices, companies should embrace these practices as important contributors to their business and financial performance outcomes (Lacey et al., 2015; Porter and Kramer, 2006; Rochlin et al., 2015).

This research uses the process-oriented indicators for product development retrieved from the scientific literature, systematized in a database and reported by (Rodrigues et al., 2016a) as a starting point for measuring the implementation of ecodesign management practices. Through the execution of a cross-analysis between the performance indicators in the database and the ecodesign management practices, two main gaps were uncovered (Rodrigues et al., 2016b): (a) the majority of the indicators are too generic and broad, and do not take fundamental specificities of ecodesign implementation into consideration, and (ii) a large number of ecodesign management practices could not be properly translated by the indicators currently proposed in the literature.

To further support the performance measurement of ecodesign implementation from a process-oriented perspective and to set the foundation for operationalizing such measurement, this paper aims at (i) proposing new process-oriented indicators to address the specificities of the ecodesign management practices and (ii) consolidating a repository of performance indicators, formed by indicators from literature and newly proposed ones. The ultimate goal of this research is to provide organizations and decision-makers in product development with a set of meaningful and aligned performance indicators that can potentially be customized, adapted and applied to their processes, in order to measure how well they are embedding ecodesign practices into their product development processes.

The process-oriented indicators are defined as a mechanism to capture the performance of the product development process itself, regardless of the type(s) and number of product(s) under development. With that, an important aspect of this research is that it takes a portfolio perspective, rather than a focus on individual products. Additionally, the particular selection, prioritization and customization of the indicators are outside of the scope of this research. Figure 1 provides a representation of the scope of this research, considered in the broader and over-arching context of corporate sustainability.

\footnotetext{
1 Environmental performance can be defined as the sum of all environmental impacts across a product's material lifecycle (Nielsen and Wenzel, 2002)
} 


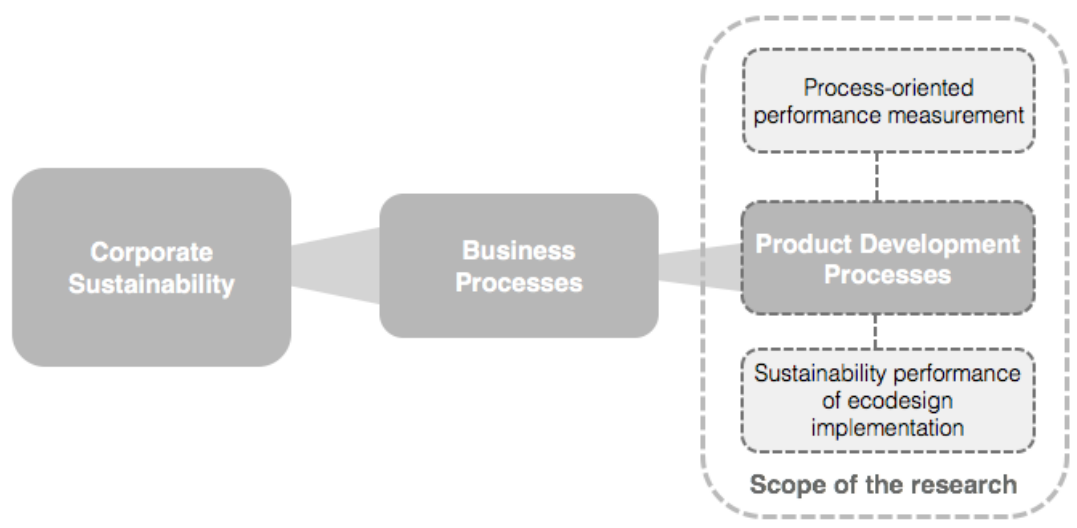

Figure 1 - Scope of research, considered within the broader context of corporate sustainability.

Essentially, this present study builds upon identified gaps in the literature of performance measurement for product development. In summary, these gaps are fundamentally related to (a) the generic nature of previously proposed indicators in the literature of product development and ecodesign, (b) the gap between the currently available indicators and the ecodesign management practices and, finally, (c) the disproportional emphasis on product-related and environmental indicators for ecodesign. Therefore, by directly tackling these gaps, the present paper reviews, proposes and evaluate new process-oriented performance indicators, which are tailored to measuring the performance of ecodesign practices at the tactical and strategic level.

The Ecodesign Maturity Model (EcoM2) (Pigosso et al., 2013) is taken as the main theoretical framework upon which the research is structured. This model was selected as a theoretical background due to its position as the only available maturity-based model for ecodesign management (Luiz et al., 2016). It systematizes ecodesign best practices into an actionable and organized application method, and therefore supports companies in the process of implementing and continuously improving ecodesign (Luiz et al., 2016; Pigosso et al., 2013). The model was proposed as a response to the multiple challenges of implementing ecodesign in a structured and systematized manner, in manufacturing companies.

Within this particular context, the focus of this research is positioned on the performance evaluation of management practices, which are the ones able to translate the ecodesign elements into more strategic business benefits, leading the path towards the construction of a business case (Carroll and Shabana, 2010) for ecodesign implementation and management. From a process perspective, each one of the ecodesign management practices can the assessed in terms of the systematization level they have within the product development. In other words, it is important to understand how systematized a certain ecodesign practice is, in order to be able to move towards more mature stages of ecodesign implementation in the company (Pigosso et al., 2013).

It is significant to remark that design is a complex and multi-faceted field of investigation, which allows for several interpretations and approaches from different schools of thought (Blessing and Chakrabarti, 2009). In this paper, we approach ecodesign from a systematic perspective on engineering design with a measurement focus. The systematic approach is fundamentally based on the German tradition of Pahl \& Beitz initiated in the 1970s (Pahl et al., 2007) and some of its related variants (Eppinger et al., 1994; Rozenfeld, 2007; Rozenfeld et al., 2006; Ulrich and Eppinger, 2008), along with the Danish school of integrated product development and systematic design (Andreasen and Hein, 2000; Tjalve, 2003). Therefore, this represents just one perspective among many others, which complement and address many of the shortcomings of the systematic approach. Other schools of thought include, with varying degrees of similarity and complementarity to the systematic approach: the theory of technical systems (Hubka and Eder, 1988), axiomatic design (Suh, 1998), visioningbased thinking (Lin and Luh, 2009), C-K theory (Hatchuel and Weil, 2003), creativity-oriented approaches (Cross, 1997; Cross and Clayburn Cross, 1995; Dorst and Cross, 2001; Eder and Hosnedl, 2008; Howard et al., 2008; Hsiao and Chou, 2004), among others.

\section{Ecodesign Maturity Model as a theoretical background}

The Ecodesign Maturity Model (EcoM2) is a management framework based upon a systematic step-by-step approach, which aims at supporting companies in the integration of ecodesign into product development processes (Pigosso et al., 2013). The model presents ecodesign best practices that were classified according to their main characteristics and object of interest (Pigosso et al., 2014), being divided into three groups: ecodesign management practices (EMP), ecodesign operational practices and methods and tools. The following 
sub-sections are dedicated to exploring the main aspects of the ecodesign practices in further details, along with other relevant characteristics of the EcoM2.

\subsection{Ecodesign management practices}

The ecodesign management practices entails a collection of 62 practices related to the integration of environmental issues into the strategic and tactical levels of the product development - these practices display elements on the process level. Examples of ecodesign management practices include "monitor the product environmental performance during use and end-of-life phases of the life cycle" and "consider and involve the total value chain for improving the environmental performance of products" (for the full list of ecodesign management practices, see Section 4). The ecodesign management practices are classified according to the phases of the product development process, based on the reference model proposed by (Amaral and Rozenfeld, 2007; Rozenfeld, 2007; Rozenfeld et al., 2006). These phases are: Product Strategic Planning, Informational Design, Conceptual Design, Detailed Design, Production Preparation, Product Launch, Product Accompanying and Monitoring, along with the Generic Activities.

Furthermore, the ecodesign management practices were also categorized according to 12 knowledge areas in ecodesign: 1) ecodesign drivers and technology identification and development; 2) technological strategy and environmental performance of technologies; 3) development of support processes and ecodesign training; 4) ecodesign incentives, awareness and communication; 5) end-of-life strategies, packaging, distribution and manufacturing; 6) strategic management of ecodesign implementation; 7) portfolio management, environmental performance evaluation and trends; 8) product's concept and requirements, ecodesign guidelines and trade-off management; 9) service offerings, legislation and standards ; 10) value chain considerations and product-related strategy; 11) ecodesign management and integration, benchmarking and tools selection; 12) environmental feasibility, phase assessments and ecodesign performance measurement.

\subsection{Ecodesign operational practices}

The ecodesign operational practices focus on product-related issues directly connected with technical characteristics of product design (e.g. shape, format, concept, material, energy etc.) and elements of its material life cycle, from raw material extraction to use and end-of-life considerations. These practices provide technical strategies for the development of environmentally enhanced products. The operational practices defined by the EcoM2 are a result of the consolidation of ecodesign guidelines and checklists and proposals for product design (Pigosso et al., 2014, 2013; Vezzoli and Manzini, 2008). The operational practices are classified into 3 levels of aggregation: 1) strategies; 2) guidelines and 3) design options. An example of strategy is "minimize material consumption" (level 1), which has "minimize or avoid packaging” an example of guideline (level 2). Finally, some design options (level 3) for this guideline could be "avoid the use of packaging that do not have a specific function" or "design the package to be part (or to become a part) of the product" or "use recyclable, reusable and returnable packaging" (Pigosso et al., 2014, 2013). The application of the operational practices depends specifically on product characteristics in regards to the life cycle and environmental aspects. Furthermore, the company's priorities for minimizing impacts can drive the application of the practices, which should be customized according to the characteristics of the company's products. Additionally, there may be specific and customized design options according to the product under development. The operational practices can be linked to ecodesign methods and tools.

\subsection{Methods and tools}

The ecodesign methods and tools comprise a set of techniques that supports the application of the ecodesign practices (both management and operational), covering a wide variety of topics of the integration of environmental issues into product development and related processes. The ecodesign methods and tools were systematized and classified according to functions, characteristics and application possibilities throughout the design process. Just like the operational practices, the methods and tools should be adapted and tailored to the company's specific product development characteristics (Pigosso et al., 2011).

These techniques are not necessarily broad and applicable. This requires specific customization processes in order to get them ready for use, according to a number of different important aspects, such as the commonness of language, culture and current state of management systems at a company. The customization can be carried out firstly as a selection of methods and tools that will support the specific ecodesign procedures to be implemented. Then the specific needs of the product development process will inform a thorough adaptation of these methods and tools(Knight and Jenkins, 2009; Pigosso et al., 2014, 2013, 2011). 


\subsection{Maturity levels}

The ecodesign maturity levels are based on the assessment of the management practices as a combination of the company's evolution level in ecodesign and the capability level (Pigosso et al., 2013).

The five evolution levels represent a recommendation of the stages to be trailed towards ecodesign implementation (Boks and Stevels, 2007; McAloone, 1998; Pigosso, 2012; Pigosso et al., 2013). The 5 evolution levels prescribed by the EcoM2 characterize recommendations of the stages to be followed towards the implementation of ecodesign. The evolution is built from level 1 - at which the organization exhibits limited experience in ecodesign and does not usually apply ecodesign practices - up to the evolution level 5, a stage at which the organization completely incorporate environmental concerns into its strategy at the corporate, business and product layers.

In particular, the five capability levels are defined as follows (Pigosso et al., 2013): (i) capability level 1 (incomplete): the ecodesign management practice is not fully applied by the company; (ii) capability level 2 (ad hoc): the practice is sporadically applied in an ad hoc fashion, with a view to correcting a specific problem or address a certain issue; (iii) capability level 3 (formalized): it means the company has defined documentation, infrastructure, responsibilities and resources for the practice; (iv) capability level 4 (controlled): at this level, the performance is measured and monitored over time with the use of specific performance indicators; (v) capability level 5 (improved): besides measuring the performance of the practice, the company allocate resources towards continuously improving the application of the practice.

The next section highlights the underlying research methodology adopted, so as to achieve such outcomes and derive the consequent contributions.

\section{Research Methodology}

Based on the systematic literature review carried out, reported and critically analyzed by (Rodrigues et al., 2016a), the overall research approach designed for this paper was molded in two phases: (i) cross-content analysis for the identification of gaps and (ii) evaluation, proposal and consolidation of indicators (Figure 2).

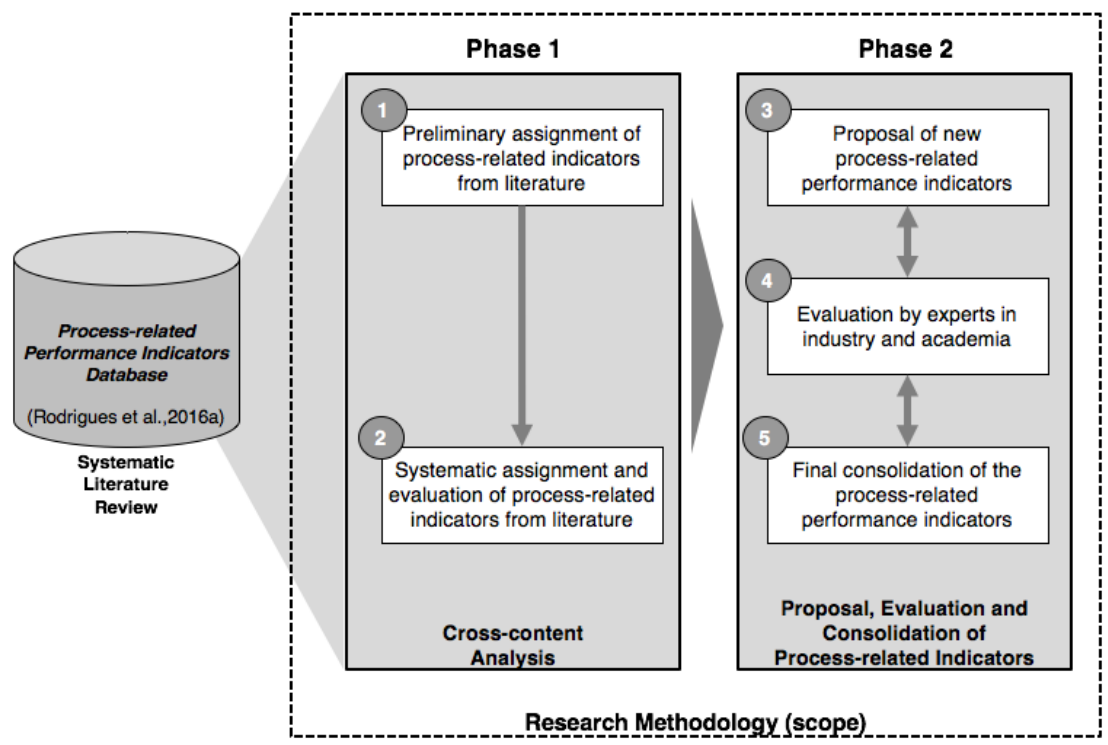

Figure 2 - Overall research approach designed in two phases with a total of 5 steps, and the delineation of the research methodology boundaries

This section describes the procedures and steps behind each one of these phases. Figure 2 shows a schematic representation of the overall research design for this paper. The following sub-sections describe each one of the phases in further detail.

\subsection{The systematic literature review as the starting point}

The systematic literature review (SLR) carried out by Rodrigues et al. (2016a) is used as starting point for this research. The subsequent study provides a critical analysis of the indicators gathered from literature. The 
systematic literature review was carried out to gather indicators for product development available in the literature. The review process followed a structured procedure, proposed by Biolchini et al., 2005, which is fundamentally based on the following steps: (1) development of a review protocol; (2) identification, evaluation and selection of studies and (3) extraction and synthesis of knowledge. The first step of building the review protocol was based on the research objective and a set of two inclusion criteria: (a) contain, at least, one indicator for product development and (b) focus on product development from a process perspective, as opposed to a product-oriented standpoint. The second step encompassed the execution of the literature search, identification of the primary studies, which were in turn evaluated and selected according to the inclusion criteria that were defined and established in protocol. As the studies were chosen, the indicators were pulled from the relevant papers and catalogued accordingly.

\subsection{Phase 1: Cross-content analysis}

The cross-content analysis was based on the 62 management practices prescribed by the EcoM2 and the process-related KPIs gathered from the systematic literature review. This analysis phase was carried forth in two integrated steps. The first step encompassed a preliminary assignment of indicators (Step 1) to practices on the basis of searches for specific keywords in the performance indicator database - these keywords were pulled out from the practice's description and inserted into the search field of the electronic spreadsheet. The following step of this stage of the research methodology (Step 2) comprised a systematized procedure which was used to evaluate the suitability of the individual indicators for measuring the ecodesign management practices.

\subsubsection{Step 1: Preliminary assignment of process-related indicators from literature}

The preliminary assignment was performed by inspecting and comparing the name and nature of the indicators pulled from literature with the characteristics of each one of the 62 ecodesign management practices. The indicators that were potentially aligned with the practice were then assigned. If no results were found, the practice was marked as not having a correspondent indicator ("N/A"). As an illustrative example of such analysis, consider the management practice "include the environmental goals into the product target specifications". The relevant keywords of this practice statement were defined as search strings (i.e. "environmental goals", "product target specifications" and synonyms).

In this example, the search for "environmental goals" returned the indicator "Number of employees with incentives linked to environmental goals". This particular indicator was not applicable to this practice example due to its focus on employees, rather than on product target specifications. Subsequently, the search for the keywords in "product target specifications" returned the indicators "\% of technical specifications met or exceeded, averaged across completions", "met performance specifications" and "met quality specifications". None of those indicators are directly applicable to the practice example. A synonym that is importantly linked to this practice example is "requirement". The search for this keyword resulted in 16 indicators (e.g. "requirement verifications trend", "accuracy of interpretation of customer requirements" etc.). Out of the 16 indicators, the indicator "degree to which the product requirements have the potential to improve sustainability" was deemed aligned to the practice example and therefore selected as a correspondent indicator.

\subsubsection{Step 2: Systematic assignment and evaluation of process-related indicators from literature}

The systematic procedure for assigning performance indicators to ecodesign management practices was derived to address the potential limitations of the preliminary assignment (Step 1). These limitations include the high dependence on the search strings and its consequent lack of robustness. Furthermore, the preliminary assignment does not configure itself as a repeatable and consistent procedure for analyzing the indicators against the practices. Therefore, there is a potential risk of missing indicators that are potentially aligned to the practice's core. Therefore, the advantages of the systematic assignment with respect to the obtained results fundamentally refer to the minimized risks of (i) missing relevant and important indicators and (ii) assigning indicators which are not particularly relevant for the practice under consideration.

Each one of the 62 ecodesign management practices was compared against the gathered indicators from literature. If a specific indicator was aligned with the practice's core meaning, it was therefore marked as assigned to that particular practice under evaluation. We define alignment in this study as the degree to which the performance indicator effectively captures the practice's meaning, totally or partially, and translates it into a measurable statement. We emphasize here that an ecodesign practice's core can have its operationalization/measurement in a company supported by an indicator. In that sense, indicators are not to be used to describing the fundamental characteristics of a practice. Instead, a prioritized, customized and aligned 
set of indicators is of fundamental use for companies willing to increase their maturity level. Figure 3 provides a schematic illustration of the systematic assignment procedure taken in this paper.

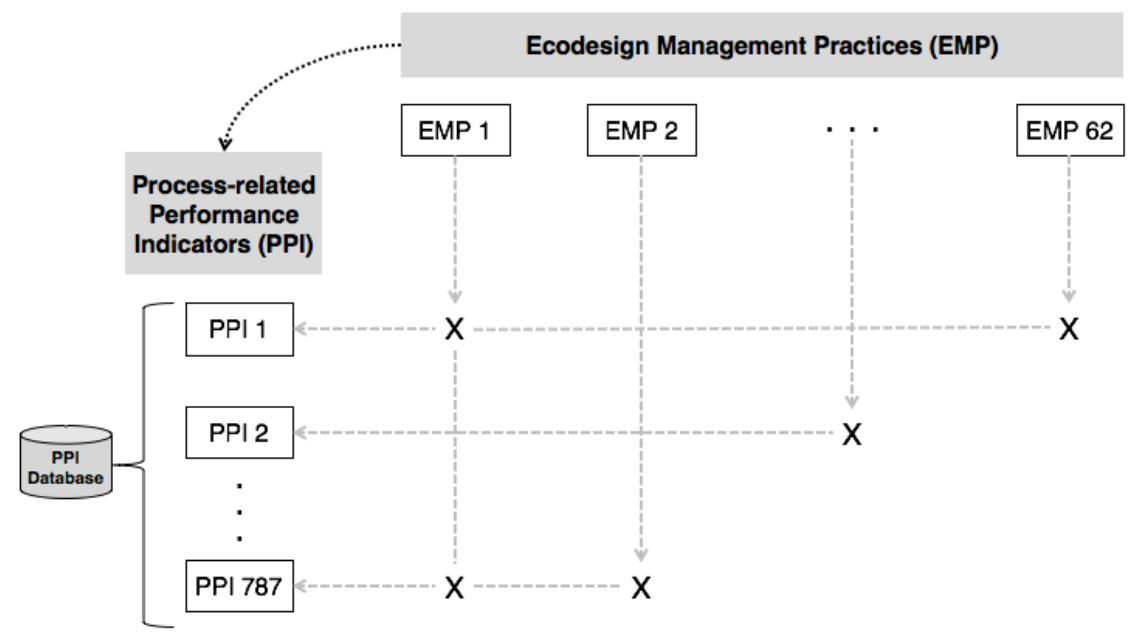

Figure 3 - Schematic illustration of the systematic procedure for assigning process-related performance indicators to ecodesign management practices

The entire procedure would lead to a total number of 48.794 evaluations ( 787 indicators $\times 62$ practices) of assignment. Although a high combinatorial complexity emerged, the overall procedure was aided and accelerated by prioritizing the evaluation of the indicators that were previously assigned during the preliminary step. It is noteworthy that all the preliminarily assigned indicators were critically evaluated in this phase and a second decision was taken based on the entire landscape of indicators. The classification scheme derived from the systematization of the indicators (Section 3.1), the preliminary assignment procedure (Section 3.2.1) and the critical analysis provided by (Rodrigues et al., 2016a) were particularly useful to pre-select groups of indicators to be prioritized during the assignment, therefore leaving less aligned indicators to be evaluated later, in a faster and more efficient pace.

As an example to illustrate the systematic assignment procedure, consider the following ecodesign management practice "collect information about applicable legal issues and standards related to the environmental performance of products". This ecodesign management practice basically deals with regulatory aspects of products' environmental performance. Therefore, to assign indicators for this specific ecodesign management practice, the studies that were focused on regulatory aspects (e.g. laws, standards and regulations etc.) (Hauser, 2001; Kim and Kim, 2015; Luz et al., 2015; Nappi and Rozenfeld, 2015, 2013; Ussui and Borsato, 2013; Vanek et al., 2008) were given priority and firstly inspected. Afterwards, all other indicators retrieved from the literature were then evaluated for alignment with the practice.

\subsection{Phase 2: Proposal of new process-related indicators, evaluation by experts and final consolidation}

Following the assignment of the performance indicators to ecodesign management practices, two issues still needed attention. Firstly, major gaps in translating the practices into performance indicators had to be addressed - namely the practices that did not have any correspondent indicator from literature and those practices which were partially covered by the indicators. Secondly, an overall evaluation of the performance indicators should be carried out in order to consolidate the findings. These issues arose mainly due to the fact that the majority of the performance indicators retrieved from literature were too generic and broad, lacking a more granular connection to the ecodesign management practices. Therefore, there was a need to propose specific indicators that would properly support the measurement of the practices. To address those two issues, Phase 2 of the research methodology fundamentally covered: (i) the proposal of new indicators to both represent the remaining practices without indicators and to complement the indicators selected from the literature and (ii) the evaluation of the performance indicators - both from literature and proposed by this research - by experts in the fields of product development and ecodesign. Phase 2 is then structured in 3 main steps: the proposal of new indicators, the evaluation of the performance indicators by experts and the final consolidation of the indicators. 


\subsubsection{Step 3: Proposal of new process-related indicators}

Based on the gap in the literature of process-related performance indicators for process development and their applicability in ecodesign management and implementation, a set of new indicators were proposed. Even though the proposal of indicators was not constrained by pre-established methodologies or standards (Keeble et al., 2003), some principles were observed and entirely respected during the phase of proposing specific performance indicators for the ecodesign management: (i) the indicator statement should be as clear and simple as possible (Keeble et al., 2003; Keong Choong, 2013); (ii) relative indicators were preferred over absolute ones in order to put the measures into context - even though the conversion between them is fairly straightforward and could be carried out to satisfying specific applications and adaptations in the company; (iii) no targets for the number of indicators for each practice were defined, since it can largely vary according to the company's strategy within its sector and key objectives (Bourne et al., 2000; Ghalayini and Noble, 1996; Keong Choong, 2013; Medori, D. \& Steeple, 2000); (iv) the stopping criterion for each practice was based on the consensus achieved among all researchers regarding the suitability and comprehensiveness of the proposed indicators, after multiple refinement iterations (Keeble et al., 2003; Kennerley and Neely, 2002) - for several practices, more than one indicator was needed in order to translate the practices' content, and consequently the process stopped when the possibilities of proposing new indicators were saturated; (v) availability of data was not particularly considered as a constraint for proposing the indicators, since it is a company- or sector-specific parameter and would limit the proposal of potentially aligned indicators - furthermore, considerations about data pertains to the realm of performance measurement systems (PMS) (Keong Choong, 2013), which entails a much broader objective than the one defined for this research.

\subsubsection{Step 4: Evaluation by experts in industry and academia}

The evaluation by experts was performed with a view to enhancing the degree of alignment and relevance of the performance indicators, both from the literature and the ones proposed in this study. A total number of eight impartial experts took part in the evaluation step. The experts were selected on the basis of their knowledge and practical experience in product development, ecodesign management/implementation and related fields, such as technology development, environmental management, product/service-systems, product lifecycle management, among others. All experts are or have recently been part of ecodesign implementation projects in a multitude of industrial sectors, in different geographies globally. Furthermore, these experts represent either (i) professionals who would be directly involved in ecodesign performance measurement and the application, customization and use of the process-related indicators (industry experts) or (ii) research-based advisors/consultants who could potentially support manufacturing companies in their implementation (academic experts). A brief summary of the experts' profiles and experiences are provided in Table 1.

Table 1 - Overview of the experts' profiles and experience

\begin{tabular}{|c|c|c|c|c|}
\hline Expert & Title/position & $\begin{array}{l}\text { Industrial sector or } \\
\text { area of research }\end{array}$ & Experience & Educational background \\
\hline $\mathbf{A}$ & Professor & $\begin{array}{l}\text { Quality management } \\
\text { and product/service- } \\
\text { systems }\end{array}$ & $\begin{array}{l}\text { Over } 12 \text { years of experience in } \\
\text { teaching and research activities }\end{array}$ & $\begin{array}{l}\text { PhD in Production Engineering, } \\
\text { with a focus on product } \\
\text { development management in } \\
\text { technology-based enterprises }\end{array}$ \\
\hline B & $\begin{array}{l}\text { Product } \\
\text { environmental } \\
\text { specialist }\end{array}$ & $\begin{array}{l}\text { Machinery and } \\
\text { construction sectors }\end{array}$ & $\begin{array}{l}\text { More than } 15 \text { years of experience as } \\
\text { product development and ecodesign } \\
\text { manager in a wide range of } \\
\text { industries, including automotive and } \\
\text { utilities }\end{array}$ & $\begin{array}{l}\text { Bachelor in Environmental } \\
\text { Engineering }\end{array}$ \\
\hline C & $\begin{array}{l}\text { Specialist in } \\
\text { product risk } \\
\text { management }\end{array}$ & $\begin{array}{l}\text { Mechanical and } \\
\text { automotive applications }\end{array}$ & $\begin{array}{l}\text { More than } 21 \text { years of experience in } \\
\text { the fields of quality management, } \\
\text { product \& technology development } \\
\text { and risk analysis in the sectors of } \\
\text { construction, electronics and } \\
\text { automobiles }\end{array}$ & $\begin{array}{l}\text { Masters in Mechanical } \\
\text { Engineering }\end{array}$ \\
\hline D & $\begin{array}{l}\text { PhD Specialist } \\
\text { in robust design }\end{array}$ & Aerospace sector & $\begin{array}{l}\text { Over } 16 \text { years of experience in } \\
\text { product \& technology development, } \\
\text { reliability and robustness in the } \\
\text { automotive and aerospace sectors }\end{array}$ & PhD in Applied Chemistry \\
\hline
\end{tabular}




\begin{tabular}{|c|c|c|c|c|}
\hline $\mathbf{E}$ & Professor & $\begin{array}{l}\text { Sustainable product } \\
\text { development }\end{array}$ & $\begin{array}{l}\text { More than } 22 \text { years of experience in } \\
\text { applied research and teaching } \\
\text { activities in the fields of sustainable } \\
\text { product development, ecodesign and } \\
\text { innovation }\end{array}$ & $\begin{array}{l}\mathrm{PhD} \text { in Mechanical Engineering } \\
\text { with emphasis on sustainable } \\
\text { product innovation }\end{array}$ \\
\hline $\mathbf{F}$ & Professor & $\begin{array}{l}\text { Product development, } \\
\text { business process } \\
\text { management, product } \\
\text { lifecycle management } \\
\text { and ecodesign }\end{array}$ & $\begin{array}{l}35 \text { years of experience in research } \\
\text { projects based on intensive } \\
\text { collaboration with industry }\end{array}$ & $\begin{array}{l}\mathrm{PhD} \text { in Mechanical Engineering } \\
\text { with focus on computer-aided } \\
\text { process planning }\end{array}$ \\
\hline G & $\begin{array}{l}\text { Professor and } \\
\text { former strategy } \\
\text { consultant }\end{array}$ & $\begin{array}{l}\text { Product development, } \\
\text { product lifecycle } \\
\text { management and } \\
\text { additive manufacturing }\end{array}$ & $\begin{array}{l}12 \text { years of experience in academic } \\
\text { research and teaching, along with } \\
\text { over } 15 \text { years in managerial roles in } \\
\text { strategy consulting firms }\end{array}$ & $\begin{array}{l}\text { PhD in Production Engineering, } \\
\text { concentrated in product } \\
\text { development and information } \\
\text { systems for product lifecycle } \\
\text { management }\end{array}$ \\
\hline H & $\begin{array}{l}\text { Consultant in } \\
\text { energy } \\
\text { efficiency and } \\
\text { sustainability of } \\
\text { human activities }\end{array}$ & $\begin{array}{l}\text { Construction and } \\
\text { building sectors }\end{array}$ & $\begin{array}{l}4 \text { years of experience in research and } \\
\text { development projects in the fields of } \\
\text { ecodesign, product development and } \\
\text { energy audits }\end{array}$ & $\begin{array}{l}\text { Bachelor in Environmental } \\
\text { Engineering, with emphasis on } \\
\text { ecodesign management and } \\
\text { implementation }\end{array}$ \\
\hline
\end{tabular}

Initially, the experts were presented with the background and contextualization of the research project and the definition of alignment (Section 3.2.2). Then, they were asked to evaluate each one of the performance indicators individually and define them as either aligned (value 1) or not aligned (value 0) with the correspondent ecodesign management practice. Due to time and resource limitations, industry experts $\mathrm{B}, \mathrm{C}$ and D evaluated only the group of proposed indicators, while academic experts A, E, F, G and industry expert $\mathrm{H}$ evaluated both the proposed indicators and the indicators from literature.

Therefore, the proposed indicators had a total of 8 evaluations, whereas the indicators from the literature had a total of 5 evaluations. In this context, a proposed indicator would only be deemed aligned if the majority of the 8 experts considered it aligned ( 5 or more experts). Similarly, for the indicators from the literature, an indicator would be considered aligned if 3 or more experts - out of the 5 - considered it aligned. The individual evaluation sessions took three hours to be performed with academic experts and two hours with industry experts, on average.

\subsubsection{Step 5: Final consolidation of the process-related performance indicators}

The final consolidation step encompassed the development of a unified document with all the indicators that had been retrieved from the literature and the new proposed indicators to fill the gaps regarding the performance measurement of the ecodesign management practices. This consolidation is fundamentally based on the results of the evaluation by the 8 experts in product development, ecodesign and related fields. Therefore, the consolidated version only represents the indicators that have been deemed aligned by the majority of the experts. Once the indicators were put together in one concise structure, they were once again revised for duplicates and spelling. In the results and discussion (Section 4), the final and consolidated version of the indicators - incorporating the results of the expert evaluation - are presented separately on Table 2 (indicators from literature) and Table $\mathbf{3}$ (proposed indicators). It is also important to underscore that some proposed qualitative indicators point directly to the development of specific scales or multidimensional indexes. However, the development of scales/indexes falls outside the scope of this paper and will be treated later as future research. 


\section{Results and Discussion}

This section presents the results and the related discussion generated from the cross-content analysis (Section 4.1) and the proposal, evaluation and final consolidation of the performance indicators (Section 4.2).

\subsection{Results and discussion from the cross-content analysis (Phase 1)}

\subsubsection{Results and discussion from the preliminary assignment of process-related indicators from literature (Step 1)}

From the entire set of 62 ecodesign management practices from the EcoM2, 32 practices did not have a correspondent indicator in the preliminary assignment (Step 1). The remaining 30 practices were assigned to a total of 27 different indicators, of which 1 specific indicator ("Number of sustainability aspects (social, environmental and economic) considered for defining performance indicators" (Ussui and Borsato, 2013)) was particularly assigned to a total of 4 different practices, and the other 26 indicators covered only one practice each.

Considering the entire database of 787 performance indicators (Rodrigues et al., 2016b), only 27 indicators were actually assigned to the 62 ecodesign management practices of the EcoM2 on the preliminary step. It is, therefore, noteworthy that the indicators that were dismissed due to misalignment with the practices were too generic and broad, and usually covering areas, topics and themes which do not typically fall within the domains of ecodesign management and implementation. Complementarily, this finding might point towards the necessity of developing new ecodesign management practices to cover gaps that are not being currently and properly addressed.

The assigned indicators were significantly concentrated in two main sources that are largely reporting sustainability-related broad indicators - 10 indicators were extracted from (Ussui and Borsato, 2013) and 7 indicators were directly extracted from the works of (Nappi and Rozenfeld, 2015, 2013). Both sources sum up almost $70 \%$ of the entire set of gathered indicators. As described in (Rodrigues et al., 2016b), the other 10 indicators were obtained from studies dealing with (i) product portfolio management indicators, derived from (Tolonen et al., 2015); (ii) lean metrics for R\&D management (Costa et al., 2014); (iii) control feedback mechanisms to support the measurement of product development (Hauser, 2001); (iv) integrated metrics for measuring innovation levels (Choi and Ko, 2010); (v) success/failure in product development processes (Griffin and Page, 1993); (vi) performance measurement system for R\&D in the construction sector (Kulatunga et al., 2011); (vii) project risk classification and metrics (Yim et al., 2015a, 2015b). None of the previously mentioned sources are directly related to the fields of ecodesign implementation and management.

\subsubsection{Results and discussion from the systematic assignment of process-related indicators from literature (Step 2)}

After carrying out the systematic assignment and reviewing the assigned indicators from literature in the preliminary step, the first result was a consolidated and reviewed list of indicators. Once the review was finalized, the consolidated list summed a total of 46 indicators, heterogeneously covering a total number of 23 ecodesign management practices. Therefore, the remaining 39 practices of the EcoM2 were not covered by any of the indicators from the literature. There was still a dominance of indicators extracted from the studies performed by (Ussui and Borsato, 2013) and (Nappi and Rozenfeld, 2015, 2013), nevertheless the number of studies covered was now larger.

Fundamentally, the indicators covering the following topics were included in the list of assigned indicators: (i) technology disruptiveness (Ganguly et al., 2010); (ii) performance indicators from a systems engineering perspective (Vanek et al., 2008); (iii) company-wide performance measurement for new product development processes (Driva et al., 2000); (iv) indicators focused on the designer level (Acosta et al., 2002); (v) indicators for product introduction from a lean standpoint (Haque and Moore, 2004); (vi) assessment of variety and creativity in concept- and idea generation (Verhaegen et al., 2013); (vii) design metrics for early supplier selection (Humphreys et al., 2007); (viii) performance indicators for collaboration management in the context of engineering design (Gendron et al., 2012) and (ix) high-level and firm-wide indicators based on the balanced score card (Bai et al., 2007).

Although a larger number of practices were covered as a result of the execution of the systematic assignment of indicators, a considerable group of practices still did not have any process-related indicator assigned (19 
practices). This particular aspect points directly to one of the findings of this research, which confirms the conclusions devised in (Rodrigues et al., 2016a): the current state-of-the-art on performance measurement for product development does not satisfactorily cover ecodesign aspects from a process-oriented perspective, making it difficult for companies and organizations in general to monitor, control and track their performance in terms of systematizing ecodesign practices into their product development processes.

In particular, the following themes of ecodesign management haven't find correspondent performance indicators in the literature: (i) portfolio management (e.g. "strategically consider the product environmental performance in the company portfolio management"); (ii) environmental performance evaluation (e.g. "evaluate the environmental performance of products during the product development process"); (iii) goal setting for environmental performance (e.g. "clearly define goals to improve environmental performance of the products under development”); (iv) environmental trends (e.g. "develop business, product and market strategies considering the environmental trends"); (v) ecodesign benchmarking (e.g. "perform internal and external benchmarking of the environmental performance of products and/or ecodesign best practices"); (vi) selection ecodesign tool and methods (e.g. "select and customize ecodesign methods and tools according to the company's needs) and (vii) management and integration of ecodesign program (e.g. "establish a prioritized program for the implementation and management of ecodesign"). Therefore, there is a relevant gap regarding performance measurement for ecodesign implementation, indicating the need for developing and proposing new process-oriented performance indicators - the object of description and analysis of the next sub-section of his paper.

4.2. Results and discussion from the proposal, evaluation and consolidation of process-related indicators (Phase 2)

\subsubsection{Consolidated list of indicators from the literature}

The 46 indicators from the literature and assigned to the 23 management practices were subjected to the evaluation of 5 experts, as discussed in the description of Step 4 of the research methodology (Section 3.3.2). To be finally considered aligned, the indicator had to have positive evaluation from 3 or more experts. The indicators that did not fulfill this criterion were deleted from the consolidated list. From the 46 indicators, 19 indicators were dismissed from the list as not aligned, totaling 27 indicators in the consolidated list which were considered aligned by at least 3 experts. These 27 indicators now cover a total of 16 ecodesign management practices. Table 2 displays the consolidated list of indicators retrieved from the literature, with the correspondent ecodesign management practice and its number.

Table 2 - Consolidated list of process-related performance indicators derived from literature

\begin{tabular}{|c|c|c|c|}
\hline \# & $\begin{array}{l}\text { Ecodesign management } \\
\text { practices }\end{array}$ & Process-oriented performance indicators derived from literature & $\begin{array}{l}\text { Suggested } \\
\text { units }\end{array}$ \\
\hline 6 & $\begin{array}{l}\text { Integrate the } \\
\text { environmental dimension } \\
\text { in the strategic decision } \\
\text { making process jointly } \\
\text { with the traditional } \\
\text { aspects }\end{array}$ & $\begin{array}{l}\text { 1. Number of sustainability aspects covered by the elements of } \\
\text { business planning (Ussui and Borsato, 2013) }\end{array}$ & N/A \\
\hline \multirow{5}{*}{12} & \multirow{5}{*}{$\begin{array}{l}\text { Collect information about } \\
\text { applicable legal issues and } \\
\text { standards related to the } \\
\text { environmental } \\
\text { performance of products }\end{array}$} & $\begin{array}{l}\text { 2. Degree to which current environmental laws for products are } \\
\text { being met (Ussui and Borsato, 2013) }\end{array}$ & N/A \\
\hline & & $\begin{array}{l}\text { 3. Monetary value of significant fines and total number of non- } \\
\text { monetary sanctions for noncompliance with environmental laws and } \\
\text { regulations (Nappi and Rozenfeld, 2015, 2013) }\end{array}$ & N/A \\
\hline & & 4. Number of lawsuits (Nappi and Rozenfeld, 2015, 2013) & N/A \\
\hline & & 5. Compliance to product standards (Vanek et al., 2008) & N/A \\
\hline & & $\begin{array}{l}\text { 6. Degree of attention to regulatory, environmental and industry } \\
\text { standards (Hauser, 2001) }\end{array}$ & N/A \\
\hline 16 & $\begin{array}{l}\text { Define a strategic } \\
\text { roadmap for the } \\
\text { development and } \\
\text { implementation of new } \\
\text { technologies that allows a } \\
\text { better environmental } \\
\text { performance over the } \\
\text { product life cycle }\end{array}$ & $\begin{array}{l}\text { 7. Technology maturity trends (Evaluation of ability to avoid } \\
\text { adoption of immature technology or to replace aging technology in a } \\
\text { timely fashion) (Vanek et al., 2008) }\end{array}$ & N/A \\
\hline 18 & $\begin{array}{l}\text { Consider the } \\
\text { environmental } \\
\text { performance as one } \\
\text { selection criteria for the } \\
\text { product concept and }\end{array}$ & $\begin{array}{l}\text { 8. Number of sustainability aspects the selected concepts have the } \\
\text { potential to improve (Ussui and Borsato, 2013) }\end{array}$ & N/A \\
\hline
\end{tabular}




\begin{tabular}{|c|c|c|c|}
\hline & design options & & \\
\hline \multirow{2}{*}{24} & \multirow{2}{*}{$\begin{array}{l}\text { Incorporate the } \\
\text { environmental aspects in } \\
\text { the identification, } \\
\text { qualification and } \\
\text { management of suppliers }\end{array}$} & $\begin{array}{l}\text { 9. Percentage of selected suppliers certified ISO } 14000 \text { (Ussui and } \\
\text { Borsato, 2013) }\end{array}$ & N/A \\
\hline & & $\begin{array}{l}\text { 10. Sustainability assessment of suppliers (Nappi and Rozenfeld, } \\
2015,2013 \text { ) }\end{array}$ & N/A \\
\hline 27 & $\begin{array}{l}\text { Develop a "green" } \\
\text { incentive scheme for the } \\
\text { ecodesign implementation } \\
\text { and management }\end{array}$ & $\begin{array}{l}\text { 11. Number of employees with incentives linked to environmental } \\
\text { goals (Nappi and Rozenfeld, 2015, 2013) }\end{array}$ & N/A \\
\hline 28 & $\begin{array}{l}\text { Select and/or develop new } \\
\text { manufacturing and } \\
\text { assembly processes with } \\
\text { better environmental } \\
\text { performance }\end{array}$ & $\begin{array}{l}\text { 12. New environmentally sound processes introduced (Nappi and } \\
\text { Rozenfeld, 2015, 2013) }\end{array}$ & N/A \\
\hline \multirow[b]{2}{*}{31} & \multirow{2}{*}{$\begin{array}{l}\text { Define the end-of-life and } \\
\text { reverse logistics strategies } \\
\text { to be addressed during } \\
\text { product development in } \\
\text { order to improve the } \\
\text { environmental } \\
\text { performance of the } \\
\text { product in the end-of-life } \\
\text { phase }\end{array}$} & $\begin{array}{l}\text { 13. Degree to which the definition of product life cycle considers } \\
\text { elements that improve sustainability at the end-of-life (Ussui and } \\
\text { Borsato, 2013) }\end{array}$ & N/A \\
\hline & & $\begin{array}{l}\text { 14. Degree to which sustainable alternatives were considered for } \\
\text { end-of-life planning (Ussui and Borsato, 2013) }\end{array}$ & N/A \\
\hline \multirow[b]{2}{*}{32} & \multirow{2}{*}{$\begin{array}{l}\text { Improve the } \\
\text { environmental } \\
\text { performance of packaging } \\
\text { and distribution during the } \\
\text { product development and } \\
\text { related processes }\end{array}$} & $\begin{array}{l}\text { 15. Degree to which sustainable alternatives for packaging were } \\
\text { verified (Ussui and Borsato, 2013) }\end{array}$ & N/A \\
\hline & & $\begin{array}{l}\text { 16. Degree to which efficient solutions for logistics were considered } \\
\text { (Ussui and Borsato, 2013) }\end{array}$ & N/A \\
\hline 39 & $\begin{array}{l}\text { Structure a systematic } \\
\text { procedure to gather } \\
\text { ecodesign-related } \\
\text { knowledge }\end{array}$ & 17. Number of knowledge/technology sources (Choi and Ko, 2010) & N/A \\
\hline 48 & $\begin{array}{l}\text { Ensure appropriate } \\
\text { communication among } \\
\text { departments and different } \\
\text { hierarchical levels } \\
\text { concerning ecodesign }\end{array}$ & 18. Communication level between departments (Choi and Ko, 2010) & N/A \\
\hline 50 & $\begin{array}{l}\text { Make environmental } \\
\text { considerations a part of } \\
\text { the daily routine of the } \\
\text { employees involved with } \\
\text { product development }\end{array}$ & $\begin{array}{l}\text { 19. Number of functions with environmental responsibilities (Nappi } \\
\text { and Rozenfeld, 2015, 2013) }\end{array}$ & N/A \\
\hline 51 & $\begin{array}{l}\text { Integrate ecodesign into } \\
\text { the product development } \\
\text { and related processes } \\
\text { standards and procedures }\end{array}$ & 20. Application of ecodesign (Nappi and Rozenfeld, 2015, 2013) & N/A \\
\hline \multirow{5}{*}{54} & \multirow{5}{*}{$\begin{array}{l}\text { Formulate, update and } \\
\text { monitor mandatory rules } \\
\text { (internal standards) and/or } \\
\text { product requirements in } \\
\text { order to comply with } \\
\text { environmental product- } \\
\text { related legislations and/or } \\
\text { regulations }\end{array}$} & $\begin{array}{l}\text { 21. Degree to which the product meets environmental legislation } \\
\text { requirements (Ussui and Borsato, 2013) }\end{array}$ & N/A \\
\hline & & $\begin{array}{l}\text { 22. Degree to which current environmental laws for products are } \\
\text { being met (Ussui and Borsato, 2013) }\end{array}$ & N/A \\
\hline & & $\begin{array}{l}\text { 23. Products that were produced under environmental or social } \\
\text { standards (Nappi and Rozenfeld, 2015, 2013) }\end{array}$ & N/A \\
\hline & & 24. Compliance to product standards (Vanek et al., 2008) & N/A \\
\hline & & $\begin{array}{l}\text { 25. Degree of attention to regulatory, environmental and industry } \\
\text { standards (Hauser, 2001) }\end{array}$ & N/A \\
\hline 60 & $\begin{array}{l}\text { Check the environmental } \\
\text { performance of products } \\
\text { during the phase } \\
\text { assessments (gates) }\end{array}$ & $\begin{array}{l}\text { 26. Number of critical/major issues assessed at the phase review } \\
\text { (Hauser, 2001) }\end{array}$ & N/A \\
\hline 61 & $\begin{array}{l}\text { Define and measure } \\
\text { environmental } \\
\text { performance indicators for } \\
\text { product improvement }\end{array}$ & $\begin{array}{l}\text { 27. Number of sustainability aspects (social, environmental and } \\
\text { economic) considered for defining performance indicators (Ussui and } \\
\text { Borsato, 2013) }\end{array}$ & N/A \\
\hline
\end{tabular}

None of the selected studies whose indicators were selected and assigned to the practices are focused purely on ecodesign management or implementation. Therefore, the main issue regarding the indicators from literature is the lack of specificity for ecodesign parameters and context. The performance indicators from literature 
partially translate the content and meaning of the practices, but they rarely cover environmental-specific attributes of the ecodesign practices. Therefore, the proposal of new indicators is needed. It must take into account the specific meaning and objective behind the practices, with the main goal of providing managers and decision-makers with performance indicators that can be properly deployed into specific metrics and relevant units within the organization.

\subsubsection{Consolidated list of proposed process-related indicators}

The second result of the Phase 2 was the consolidated version of the proposed performance indicators for the ecodesign management practices. Following the procedure and principles stated for the proposal of new indicators (Section 3.3.1), they were proposed in order to complement the ones assigned from the literature and to cover the entire set of 62 management practices of the EcoM2. Similarly, the proposed indicators were subjected to the evaluation of 8 experts. The indicators which received the positive evaluation of 5 experts or more were finally considered as aligned to the ecodesign management practice and then added into the consolidated list. The indicators which did not achieve the mark of 5 experts were instantly disregarded as not aligned. Having been through the expert evaluation, 21 indicators were deemed as not aligned and therefore excluded from the consolidated list. Table 3 displays the final and consolidated list of 114 indicators which were evaluated as aligned by 5 experts or more.

It is noteworthy that the proposed indicators are not meant to be an end result in terms of achieving superior sustainability performance, but rather a means to managing it. For instance, some of the indicators proposed in this paper are to be measured on the basis of a numerical count of different entities (e.g. people, drivers, functional areas, products, etc.), and these counts form the basis of how companies can structure their performance measurement of product development processes, with a view to achieving sustainable performance by continuous monitoring and enhancement. Proposing to apply these indicators alone, in their raw data formats, would not be sufficient when seeking for improved corporate sustainability performance, but the customization and application of these indicators can chart a path for companies to develop their competences further, in terms of resources, processes and responsibilities.

Table 3 - Consolidated list of the proposed process-related performance indicators

\begin{tabular}{|c|c|c|c|}
\hline \# & $\begin{array}{l}\text { Ecodesign management } \\
\text { practices }\end{array}$ & $\begin{array}{l}\text { Proposed process-related performance } \\
\text { indicators }\end{array}$ & Suggested units \\
\hline 1 & $\begin{array}{l}\text { Examine the relevant internal } \\
\text { and external drivers for the } \\
\text { development of products with a } \\
\text { better environmental } \\
\text { performance }\end{array}$ & $\begin{array}{l}\text { 1. Number of examined internal/external } \\
\text { drivers for ecodesign }\end{array}$ & Number of drivers examined \\
\hline \multirow{3}{*}{2} & \multirow{3}{*}{$\begin{array}{l}\text { Assess technological and } \\
\text { market trends (including new } \\
\text { customer requirements) related } \\
\text { to ecodesign }\end{array}$} & $\begin{array}{l}\text { 2. Rate of market trends }(\%) \text { related to } \\
\text { ecodesign }\end{array}$ & $\begin{array}{l}\text { Percentage of market trends (in } \\
\text { relation to the total number of } \\
\text { trends) }\end{array}$ \\
\hline & & $\begin{array}{l}\text { 3. Rate of technology trends }(\%) \text { related to } \\
\text { ecodesign }\end{array}$ & $\begin{array}{l}\text { Percentage of technology trends (in } \\
\text { relation to the total number of } \\
\text { trends) }\end{array}$ \\
\hline & & $\begin{array}{l}\text { 4. Rate of customer demands }(\%) \text { related to } \\
\text { ecodesign }\end{array}$ & $\begin{array}{l}\text { Percentage of customer demands } \\
\text { (in relation to the total number of } \\
\text { trends) }\end{array}$ \\
\hline \multirow[t]{2}{*}{3} & \multirow{2}{*}{$\begin{array}{l}\text { Ensure alignment among } \\
\text { strategic and operational } \\
\text { dimensions concerning } \\
\text { environmental issues in product } \\
\text { development }\end{array}$} & $\begin{array}{l}\text { 5. Product development alignment with } \\
\text { business strategy concerning environmental } \\
\text { issues }\end{array}$ & Dimensionless (qualitative/scale) \\
\hline & & $\begin{array}{l}\text { 6. Alignment with corporate strategy and core } \\
\text { competence concerning environmental issues }\end{array}$ & Dimensionless (qualitative/scale) \\
\hline \multirow{3}{*}{4} & \multirow{3}{*}{$\begin{array}{l}\text { Clearly define the goals to } \\
\text { improve environmental } \\
\text { performance of the products } \\
\text { under development }\end{array}$} & 7. Rate of environmental goals (\%) & $\begin{array}{l}\text { Percentage of environmental goals } \\
\text { (in relation to the total number of } \\
\text { goals) }\end{array}$ \\
\hline & & 8. Ambition level of environmental goals & Dimensionless (qualitative/scale) \\
\hline & & 9. Feasibility of environmental goals & Dimensionless (qualitative/scale) \\
\hline \multirow[t]{2}{*}{5} & \multirow[t]{2}{*}{$\begin{array}{l}\text { Include the environmental } \\
\text { goals into the product target } \\
\text { specifications }\end{array}$} & $\begin{array}{l}\text { 10. Rate of environmental requirements }(\%) \text { in } \\
\text { product target specifications }\end{array}$ & $\begin{array}{l}\text { Percentage of environmental } \\
\text { requirements (in relation to the total } \\
\text { number of requirements) }\end{array}$ \\
\hline & & 11. Integration level of environmental & Dimensionless (qualitative/scale) \\
\hline
\end{tabular}




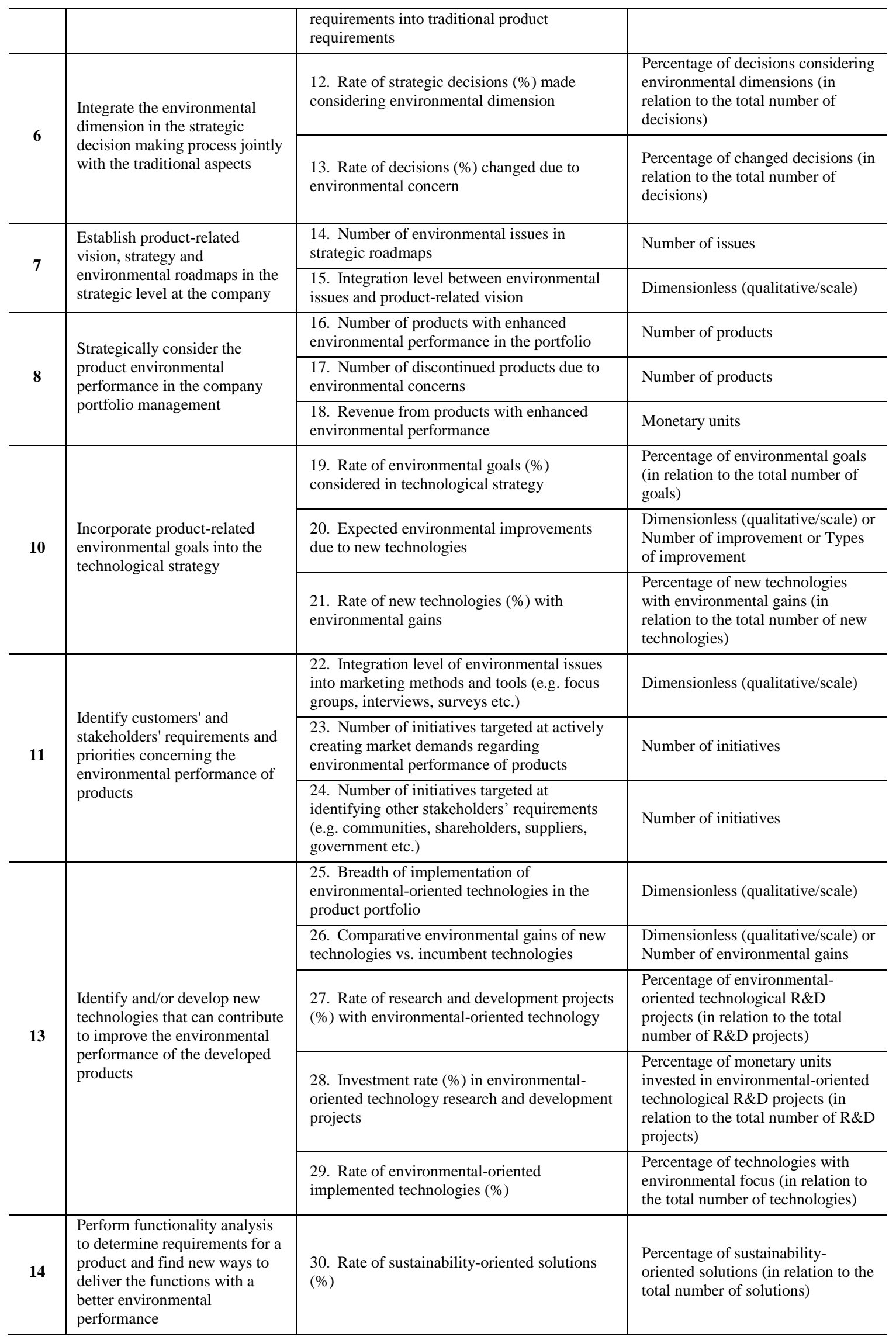




\begin{tabular}{|c|c|c|c|}
\hline \multirow{3}{*}{15} & \multirow{3}{*}{$\begin{array}{l}\text { Improve the interaction } \\
\text { between product and service } \\
\text { developments in order to } \\
\text { explore the potential to offer } \\
\text { solutions with a better } \\
\text { environmental performance }\end{array}$} & $\begin{array}{l}\text { 31. Rate of products }(\%) \text { with service } \\
\text { offerings enabling an increased environmental } \\
\text { performance }\end{array}$ & $\begin{array}{l}\text { Percentage of products with service } \\
\text { offering that enables superior } \\
\text { environmental performance (in } \\
\text { relation to the total number of } \\
\text { products) }\end{array}$ \\
\hline & & $\begin{array}{l}\text { 32. Revenue from product-service integrated } \\
\text { offerings with superior environmental } \\
\text { performance }\end{array}$ & Monetary units \\
\hline & & $\begin{array}{l}\text { 33. Number of new environmental-oriented } \\
\text { business model opportunities identified due to } \\
\text { product-service integrated offerings }\end{array}$ & Number of new opportunities \\
\hline \multirow{3}{*}{16} & \multirow{3}{*}{$\begin{array}{l}\text { Define a strategic roadmap for } \\
\text { the development and } \\
\text { implementation of new } \\
\text { technologies that allows a } \\
\text { better environmental } \\
\text { performance over the product } \\
\text { life cycle }\end{array}$} & $\begin{array}{l}\text { 34. Rate of environmentally-oriented } \\
\text { technology }{ }^{2}(\%) \text { in the roadmap }\end{array}$ & $\begin{array}{l}\text { Percentage of environmental- } \\
\text { oriented technologies (in relation to } \\
\text { the total number of technologies in } \\
\text { the roadmap) }\end{array}$ \\
\hline & & $\begin{array}{l}\text { 35. Investment rate (\%) in environmentally- } \\
\text { oriented technology research and development } \\
\text { projects }\end{array}$ & $\begin{array}{l}\text { Percentage of monetary units } \\
\text { invested in environmental-oriented } \\
\text { technology R\&D projects (in } \\
\text { relation to the total amount invested } \\
\text { on } R \& D \text { projects) }\end{array}$ \\
\hline & & $\begin{array}{l}\text { 36. Rate of environmentally-oriented } \\
\text { implemented technologies (\%) }\end{array}$ & $\begin{array}{l}\text { Percentage of environmental- } \\
\text { oriented technologies that were } \\
\text { implemented (in relation to the total } \\
\text { number of implemented } \\
\text { technologies) }\end{array}$ \\
\hline 17 & $\begin{array}{l}\text { Evaluate the environmental } \\
\text { performance of technologies }\end{array}$ & $\begin{array}{l}\text { 37. Rate of technologies (\%) with impact } \\
\text { assessment }\end{array}$ & $\begin{array}{l}\text { Percentage of technologies with } \\
\text { impact assessment (in relation to } \\
\text { the total number of technologies) }\end{array}$ \\
\hline 18 & $\begin{array}{l}\text { Consider the environmental } \\
\text { performance as one selection } \\
\text { criterion for the product } \\
\text { concept and design options }\end{array}$ & $\begin{array}{l}\text { 38. Rate of new environmentally-oriented } \\
\operatorname{concepts}^{3}(\%)\end{array}$ & $\begin{array}{l}\text { Percentage of new environmental- } \\
\text { oriented concepts (in relation to the } \\
\text { total number of concepts) }\end{array}$ \\
\hline \multirow{3}{*}{19} & \multirow{3}{*}{$\begin{array}{l}\text { Evaluate the environmental } \\
\text { performance of products during } \\
\text { the product development } \\
\text { process }\end{array}$} & $\begin{array}{l}\text { 39. Rate of products }(\%) \text { with evaluation of } \\
\text { environmental performance in the early stages } \\
\text { of product development process }\end{array}$ & $\begin{array}{l}\text { Percentage of products with } \\
\text { evaluation of environmental } \\
\text { performance in the early stages (in } \\
\text { relation to the total number of } \\
\text { products under development) }\end{array}$ \\
\hline & & $\begin{array}{l}\text { 40. Rate of products }(\%) \text { with evaluation of } \\
\text { environmental performance in the late stages } \\
\text { of product development process }\end{array}$ & $\begin{array}{l}\text { Percentage of products with } \\
\text { evaluation of environmental } \\
\text { performance in the late stages (in } \\
\text { relation to the total number of } \\
\text { products under development) }\end{array}$ \\
\hline & & $\begin{array}{l}\text { 41. Rate of products }(\%) \text { using the results of } \\
\text { environmental evaluation during decision- } \\
\text { making in the product development process }\end{array}$ & $\begin{array}{l}\text { Percentage of products with } \\
\text { evaluation of environmental } \\
\text { performance with results used for } \\
\text { decision-making in product } \\
\text { development (in relation to the total } \\
\text { number of products under } \\
\text { development) }\end{array}$ \\
\hline 20 & $\begin{array}{l}\text { Establish priorities on the } \\
\text { environmental impacts to be } \\
\text { minimized over the entire life } \\
\text { cycle of the product }\end{array}$ & $\begin{array}{l}\text { 42. Rate of products }(\%) \text { with established } \\
\text { priorities of environmental impacts to be } \\
\text { minimized over the entire life cycle }\end{array}$ & $\begin{array}{l}\text { Percentage of products with } \\
\text { establish priorities for } \\
\text { environmental impacts (in relation } \\
\text { to the total number of products) }\end{array}$ \\
\hline 21 & $\begin{array}{l}\text { Consider the trade-offs among } \\
\text { the environmental requirements } \\
\text { and the traditional requirements } \\
\text { of a product (such as quality } \\
\text { and cost) }\end{array}$ & $\begin{array}{l}\text { 43. Rate of products (\%) with prioritized } \\
\text { environmental requirements in the trade-off } \\
\text { analysis }\end{array}$ & $\begin{array}{l}\text { Percentage of products with } \\
\text { prioritized environmental } \\
\text { requirements in trade-off analysis } \\
\text { (in relation to the total number of } \\
\text { products) }\end{array}$ \\
\hline
\end{tabular}

${ }^{2}$ Environmentally-oriented technology can be defined as a new technology which is fundamentally aimed at reducing the product's environmental burden, compared to the incumbent technologies.

${ }^{3}$ An environmentally-oriented concept is a concept which is fundamentally targeted at reducing the product's overall environmental burden, compared to other concepts which doesn’t have environmental performance as a selection criterion. 


\begin{tabular}{|c|c|c|c|}
\hline 22 & $\begin{array}{l}\text { Identify the ecodesign } \\
\text { guidelines that can be applied } \\
\text { in product design in order to } \\
\text { increase the environmental } \\
\text { performance of the product } \\
\text { under development }\end{array}$ & $\begin{array}{l}\text { 44. Alignment level between ecodesign } \\
\text { guidelines and the product's environmental } \\
\text { targets }\end{array}$ & Dimensionless (qualitative/scale) \\
\hline 23 & $\begin{array}{l}\text { Develop and/or customize } \\
\text { environmental product-related } \\
\text { guidelines to support product } \\
\text { development }\end{array}$ & $\begin{array}{l}\text { 45. Customization level of ecodesign } \\
\text { guidelines }\end{array}$ & Dimensionless (qualitative/scale) \\
\hline \multirow{4}{*}{24} & \multirow{4}{*}{$\begin{array}{l}\text { Incorporate the environmental } \\
\text { aspects in the identification, } \\
\text { qualification and management } \\
\text { of suppliers }\end{array}$} & $\begin{array}{l}\text { 46. Rate of suppliers (\%) identified, qualified } \\
\text { and managed based on their environmental } \\
\text { performance }\end{array}$ & $\begin{array}{l}\text { Percentage of suppliers identified, } \\
\text { qualified and managed based on } \\
\text { environmental performance (in } \\
\text { relation to the total number of } \\
\text { suppliers) }\end{array}$ \\
\hline & & $\begin{array}{l}\text { 47. Rate of relationships }(\%) \text { terminated due } \\
\text { to low or non-compliant environmental } \\
\text { performance }\end{array}$ & $\begin{array}{l}\text { Percentage of } \\
\text { relationships/contracts terminated } \\
\text { due to low or non-compliant } \\
\text { environmental performance (in } \\
\text { relation to the total number of } \\
\text { terminated relationships/contracts } \\
\text { or the total number of } \\
\text { relationships/contracts) }\end{array}$ \\
\hline & & $\begin{array}{l}\text { 48. Rate of new suppliers }(\%) \text { identified and } \\
\text { selected due to their superior product-related } \\
\text { environmental performance }\end{array}$ & $\begin{array}{l}\text { Percentage of new suppliers } \\
\text { identified and selected due to } \\
\text { environmental performance (in } \\
\text { relation to the total number of new } \\
\text { suppliers) }\end{array}$ \\
\hline & & $\begin{array}{l}\text { 49. Coverage of environmental aspects (\%) in } \\
\text { the identification, qualification and } \\
\text { management of suppliers }\end{array}$ & Dimensionless (qualitative/scale) \\
\hline \multirow[b]{2}{*}{25} & \multirow{2}{*}{$\begin{array}{l}\text { Consider and involve the total } \\
\text { value chain for improving the } \\
\text { environmental performance of } \\
\text { products }\end{array}$} & $\begin{array}{l}\text { 50. Degree of value chain partners' } \\
\text { involvement in improving the environmental } \\
\text { performance of products }\end{array}$ & Dimensionless (qualitative/scale) \\
\hline & & $\begin{array}{l}\text { 51. Rate of downstream/upstream value chain } \\
\text { partners }(\%) \text { involved in the improvement of } \\
\text { environmental performance of products }\end{array}$ & $\begin{array}{l}\text { Percentage of partners involved in } \\
\text { improving environmental } \\
\text { performance of products (in } \\
\text { relation to the total number of } \\
\text { partners) }\end{array}$ \\
\hline \multirow{2}{*}{26} & \multirow{2}{*}{$\begin{array}{l}\text { Establish cooperation programs } \\
\text { and joint goals with suppliers } \\
\text { and partners aiming to improve } \\
\text { the environmental performance } \\
\text { of products }\end{array}$} & $\begin{array}{l}\text { 52. Number of cooperation programs focused } \\
\text { on environmental performance improvement } \\
\text { in collaboration with value chain partners }\end{array}$ & Number of programs \\
\hline & & $\begin{array}{l}\text { 53. Number of joint goals in the value chain } \\
\text { focused on environmental performance } \\
\text { improvement }\end{array}$ & Number of joint goals \\
\hline 27 & $\begin{array}{l}\text { Develop a "green" incentive } \\
\text { scheme for the ecodesign } \\
\text { implementation and } \\
\text { management }\end{array}$ & $\begin{array}{l}\text { 54. Coverage of environmental-related } \\
\text { incentives linked to ecodesign implementation } \\
\text { and management across hierarchical levels }\end{array}$ & Dimensionless (qualitative/scale) \\
\hline \multirow{4}{*}{28} & \multirow{4}{*}{$\begin{array}{l}\text { Select and/or develop new } \\
\text { manufacturing and assembly } \\
\text { processes with better } \\
\text { environmental performance }\end{array}$} & $\begin{array}{l}\text { 55. Integration level of environmental } \\
\text { considerations in designing new } \\
\text { manufacturing and assembly processes }\end{array}$ & Dimensionless (qualitative/scale) \\
\hline & & $\begin{array}{l}\text { 56. Integration level of environmental } \\
\text { considerations in the selection of new } \\
\text { manufacturing and assembly processes }\end{array}$ & Dimensionless (qualitative/scale) \\
\hline & & $\begin{array}{l}\text { 57. Rate of new manufacturing and assembly } \\
\text { processes }(\%) \text { with increased environmental } \\
\text { performance }\end{array}$ & $\begin{array}{l}\text { Percentage of new } \\
\text { manufacturing/assembly processes } \\
\text { with increased environmental } \\
\text { performance (in relation to the total } \\
\text { number of new } \\
\text { manufacturing/assembly processes } \\
\text { selected or developed) }\end{array}$ \\
\hline & & $\begin{array}{l}\text { 58. Investment rate }(\%) \text { in new manufacturing } \\
\text { and assembly processes with increased } \\
\text { environmental performance }\end{array}$ & $\begin{array}{l}\text { Percentage of monetary units } \\
\text { invested in new } \\
\text { manufacturing/assembly processes } \\
\text { with a view to increasing } \\
\text { environmental performance (in } \\
\text { relation to the total amount invested } \\
\text { in new manufacturing/assembly } \\
\text { processes) }\end{array}$ \\
\hline
\end{tabular}




\begin{tabular}{|c|c|c|c|}
\hline \multirow{3}{*}{29} & \multirow{3}{*}{$\begin{array}{l}\text { Optimize the existing } \\
\text { production processes in order } \\
\text { to improve the environmental } \\
\text { performance of products during } \\
\text { manufacturing }\end{array}$} & $\begin{array}{l}\text { 59. Enhancement of environmental } \\
\text { performance of manufacturing processes over } \\
\text { time }\end{array}$ & Dimensionless (qualitative/scale) \\
\hline & & $\begin{array}{l}\text { 60. Rate of actions/initiatives/programs }(\%) \\
\text { towards enhancing environmental performance } \\
\text { of manufacturing processes }\end{array}$ & $\begin{array}{l}\text { Percentage of } \\
\text { actions/initiatives/programs with } \\
\text { environmental focus for } \\
\text { manufacturing processes (in } \\
\text { relation to the total number of } \\
\text { action/initiatives/programs targeted } \\
\text { at improving manufacturing } \\
\text { processes) }\end{array}$ \\
\hline & & $\begin{array}{l}\text { 61. Investment in enhancing environmental } \\
\text { performance of manufacturing processes }\end{array}$ & Monetary units \\
\hline \multirow{2}{*}{30} & \multirow{2}{*}{$\begin{array}{l}\text { Develop the technical support } \\
\text { processes (e.g. maintenance, } \\
\text { change of spare parts, etc.) } \\
\text { aiming to improve the } \\
\text { environmental performance of } \\
\text { the product over its entire life } \\
\text { cycle }\end{array}$} & $\begin{array}{l}\text { 62. Rate of products }(\%) \text { in the portfolio with } \\
\text { extended lifetime due to environmental-related } \\
\text { technical support processes }\end{array}$ & $\begin{array}{l}\text { Percentage of products with } \\
\text { extended lifetime due to technical } \\
\text { support processes (in relation to the } \\
\text { total number of products in the } \\
\text { portfolio) }\end{array}$ \\
\hline & & $\begin{array}{l}\text { 63. Rate of products (\%) in the portfolio with } \\
\text { increased operational efficiency due to } \\
\text { environmental-related technical support } \\
\text { processes }\end{array}$ & $\begin{array}{l}\text { Percentage of products with } \\
\text { increased efficiency due to } \\
\text { technical support processes (in } \\
\text { relation to the total number of } \\
\text { products in the portfolio) }\end{array}$ \\
\hline 31 & $\begin{array}{l}\text { Define the end-of-life and } \\
\text { reverse logistics strategies to be } \\
\text { addressed during product } \\
\text { development in order to } \\
\text { improve the environmental } \\
\text { performance of the product in } \\
\text { the end-of-life phase }\end{array}$ & $\begin{array}{l}\text { 64. Rate of products }(\%) \text { in the portfolio with } \\
\text { defined end-of-life and reverse logistics } \\
\text { strategies }\end{array}$ & $\begin{array}{l}\text { Percentage of products with } \\
\text { defined end-of-life and reverse } \\
\text { logistics (in relation to the total } \\
\text { number of products in the portfolio) }\end{array}$ \\
\hline 32 & $\begin{array}{l}\text { Improve the environmental } \\
\text { performance of packaging and } \\
\text { distribution during the product } \\
\text { development and related } \\
\text { processes }\end{array}$ & $\begin{array}{l}\text { 65. Rate of products (\%) with } \\
\text { environmentally-enhanced } \\
\text { packaging/distribution }\end{array}$ & $\begin{array}{l}\text { Percentage of products with } \\
\text { environmentally-enhanced } \\
\text { packaging/distribution (in relation } \\
\text { to the total number of products in } \\
\text { the portfolio) }\end{array}$ \\
\hline \multirow[t]{2}{*}{33} & \multirow{2}{*}{$\begin{array}{l}\text { Elaborate and communicate } \\
\text { recommendations to consumers } \\
\text { on how to improve the } \\
\text { environmental performance of } \\
\text { the product during the use and } \\
\text { end-of-life phases }\end{array}$} & $\begin{array}{l}\text { 66. Rate of products (\%) with environmental } \\
\text { recommendations to consumers regarding use } \\
\text { and end-of-life }\end{array}$ & $\begin{array}{l}\text { Percentage of products } \\
\text { environmental recommendations to } \\
\text { consumers regarding use and end- } \\
\text { of-life (in relation to the total } \\
\text { number of products in the portfolio) }\end{array}$ \\
\hline & & $\begin{array}{l}\text { 67. Relevance of the information provided to } \\
\text { consumers regarding the product's use and } \\
\text { end-of-life }\end{array}$ & Dimensionless (qualitative/scale) \\
\hline 34 & $\begin{array}{l}\text { Communicate the } \\
\text { environmental performance and } \\
\text { benefits as part of the total } \\
\text { value proposition of the } \\
\text { product, exploring the green } \\
\text { marketing opportunities }\end{array}$ & 68. Rate of products (\%) with eco-label & $\begin{array}{l}\text { Percentage of products with eco- } \\
\text { label (in relation to the total } \\
\text { number of products in the portfolio) }\end{array}$ \\
\hline 35 & $\begin{array}{l}\text { Monitor the product } \\
\text { environmental performance } \\
\text { during use and end-of-life } \\
\text { phases of the life cycle }\end{array}$ & $\begin{array}{l}\text { 69. Rate of products }(\%) \text { monitored during use } \\
\text { and end-of-life phases }\end{array}$ & $\begin{array}{l}\text { Percentage of products monitored } \\
\text { during use and end-of-life (in } \\
\text { relation to the total number of } \\
\text { products the company has) }\end{array}$ \\
\hline \multirow[b]{2}{*}{36} & \multirow{2}{*}{$\begin{array}{l}\text { Communicate to customer and } \\
\text { stakeholders the improvements } \\
\text { on the product environmental } \\
\text { performance and consequent } \\
\text { economic gains }\end{array}$} & $\begin{array}{l}\text { 70. Degree to which product-related } \\
\text { environmental information is shared with } \\
\text { stakeholders }\end{array}$ & Dimensionless (qualitative/scale) \\
\hline & & $\begin{array}{l}\text { 71. Rate of stakeholders }(\%) \text { informed about } \\
\text { the total amount of economic gains related to } \\
\text { ecodesign }\end{array}$ & $\begin{array}{l}\text { Percentage of stakeholders } \\
\text { informed about economic gains (in } \\
\text { relation to the total number of } \\
\text { stakeholders) }\end{array}$ \\
\hline 37 & $\begin{array}{l}\text { Supply the product } \\
\text { development process with } \\
\text { information related to the } \\
\text { environmental performance of } \\
\text { materials, processes and } \\
\text { components in the whole } \\
\text { product life cycle phases }\end{array}$ & $\begin{array}{l}\text { 72. Rate of consideration of information }(\%) \\
\text { collected during life cycle in new product } \\
\text { development projects }\end{array}$ & $\begin{array}{l}\text { Dimensionless (qualitative/scale) or } \\
\text { Percentage of the amount of } \\
\text { environmental information } \\
\text { considered as input for new } \\
\text { development projects in relation to } \\
\text { the total amount of environmental } \\
\text { information collected during life } \\
\text { cycle }\end{array}$ \\
\hline
\end{tabular}




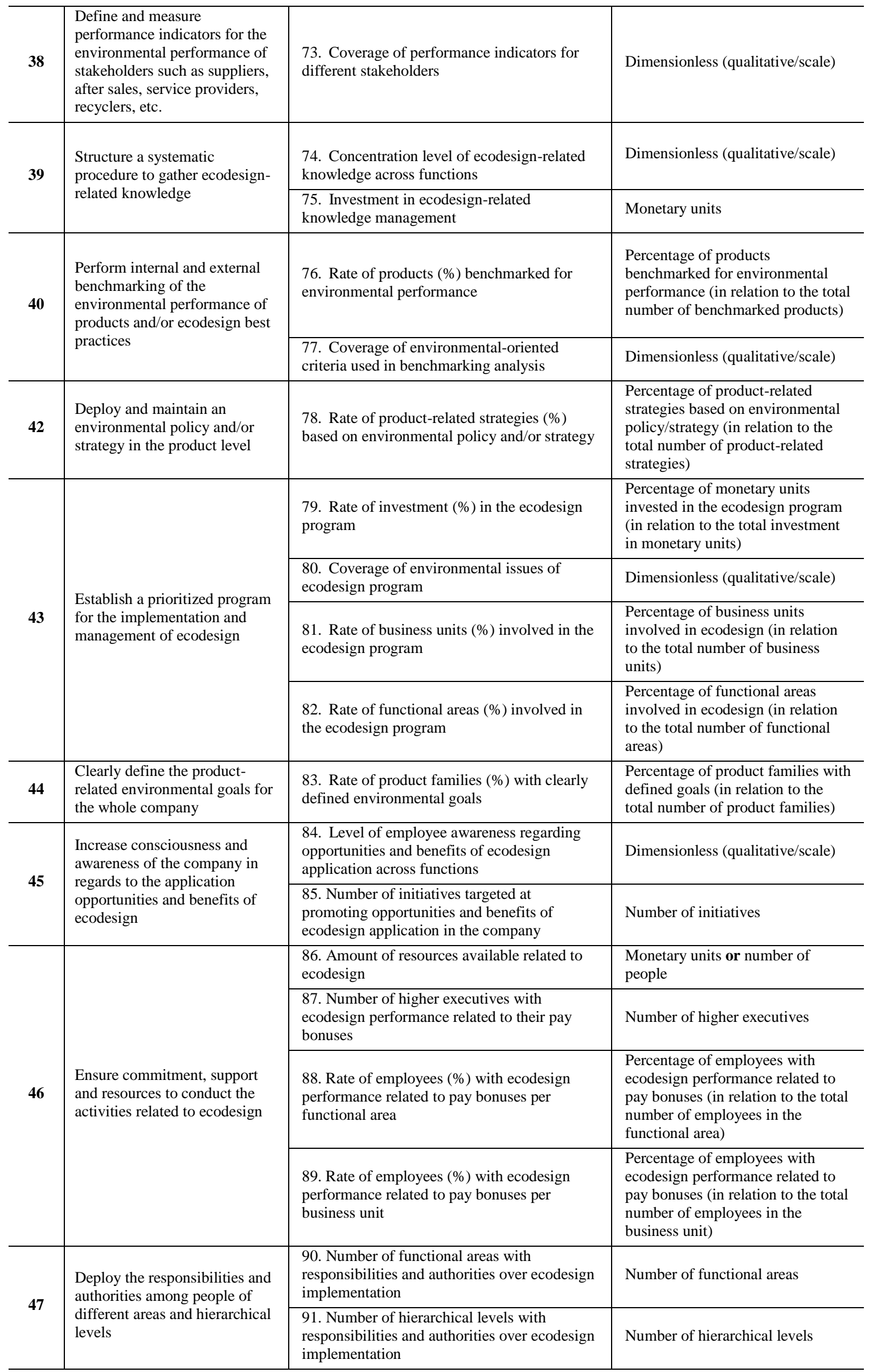




\begin{tabular}{|c|c|c|c|}
\hline \multirow{4}{*}{49} & \multirow{4}{*}{$\begin{array}{l}\text { Provide ecodesign-related } \\
\text { training for the employees } \\
\text { involved in the product } \\
\text { development and related } \\
\text { processes }\end{array}$} & $\begin{array}{l}\text { 92. Rate of employees (\%) trained in } \\
\text { ecodesign-related topics }\end{array}$ & $\begin{array}{l}\text { Percentage of employees trained in } \\
\text { ecodesign-related topics (in relation } \\
\text { to the total number of employees or } \\
\text { the total number of employees } \\
\text { working on ecodesign) }\end{array}$ \\
\hline & & $\begin{array}{l}\text { 93. Level of employees' knowledge regarding } \\
\text { ecodesign-related topics }\end{array}$ & Dimensionless (qualitative/scale) \\
\hline & & $\begin{array}{l}\text { 94. Rate of acquired knowledge (\%) shared } \\
\text { among other employees }\end{array}$ & Dimensionless (qualitative/scale) \\
\hline & & $\begin{array}{l}\text { 95. Level of access to ecodesign knowledge } \\
\text { base by employees }\end{array}$ & Dimensionless (qualitative/scale) \\
\hline 50 & $\begin{array}{l}\text { Make environmental } \\
\text { considerations a part of the } \\
\text { daily routine of the employees } \\
\text { involved with product } \\
\text { development }\end{array}$ & $\begin{array}{l}\text { 96. Integration level of ecodesign into } \\
\text { employees' daily activities }\end{array}$ & Dimensionless (qualitative/scale) \\
\hline \multirow{2}{*}{51} & \multirow{2}{*}{$\begin{array}{l}\text { Integrate ecodesign into the } \\
\text { product development and } \\
\text { related processes standards and } \\
\text { procedures }\end{array}$} & $\begin{array}{l}\text { 97. Maturity level of ecodesign } \\
\text { implementation and management }\end{array}$ & Dimensionless (qualitative/scale) \\
\hline & & $\begin{array}{l}\text { 98. Integration level of ecodesign into product } \\
\text { development standards and procedures }\end{array}$ & Dimensionless (qualitative/scale) \\
\hline \multirow[b]{2}{*}{52} & \multirow{2}{*}{$\begin{array}{l}\text { Conduct management reviews } \\
\text { to evaluate the effectiveness of } \\
\text { the environmental issues } \\
\text { consideration in the product } \\
\text { development and related } \\
\text { processes }\end{array}$} & $\begin{array}{l}\text { 99. Frequency of ecodesign management } \\
\text { reviews }\end{array}$ & $\begin{array}{l}\text { Reviews per unit of time (e.g. } \\
\text { month, quarter, year etc.) }\end{array}$ \\
\hline & & $\begin{array}{l}\text { 100. Effectiveness of corrective actions taken } \\
\text { after ecodesign management reviews }\end{array}$ & Dimensionless (qualitative/scale) \\
\hline \multirow{4}{*}{53} & \multirow{4}{*}{$\begin{array}{l}\text { Select and customize ecodesign } \\
\text { methods and tools according to } \\
\text { the company's needs }\end{array}$} & $\begin{array}{l}\text { 101. Integration level of ecodesign methods } \\
\text { and tools into the product development process }\end{array}$ & Dimensionless (qualitative/scale) \\
\hline & & $\begin{array}{l}\text { 102. Integration level of environmental issues } \\
\text { into existing methods and tools }\end{array}$ & Dimensionless (qualitative/scale) \\
\hline & & $\begin{array}{l}\text { 103. Coverage of ecodesign methods and tool } \\
\text { across the product development process }\end{array}$ & Dimensionless (qualitative/scale) \\
\hline & & $\begin{array}{l}\text { 104. Number of employees properly trained or } \\
\text { capable of using ecodesign methods, tools and } \\
\text { outputs }\end{array}$ & Number of employees \\
\hline \multirow[b]{2}{*}{54} & \multirow{2}{*}{$\begin{array}{l}\text { Formulate, update and monitor } \\
\text { mandatory rules (internal } \\
\text { standards) and/or product } \\
\text { requirements in order to } \\
\text { comply with environmental } \\
\text { product-related legislations } \\
\text { and/or regulations }\end{array}$} & $\begin{array}{l}\text { 105. Comprehensiveness of product-related } \\
\text { environmental legislation requirements }\end{array}$ & Dimensionless (qualitative/scale) \\
\hline & & $\begin{array}{l}\text { 106. Compliance level with product-related } \\
\text { environmental legislation requirements }\end{array}$ & Dimensionless (qualitative/scale) \\
\hline 55 & $\begin{array}{l}\text { Effectively integrate product- } \\
\text { related environmental goals } \\
\text { into the corporate strategy }\end{array}$ & $\begin{array}{l}\text { 107. Integration level of environmental goals } \\
\text { into the corporate strategy }\end{array}$ & Dimensionless (qualitative/scale) \\
\hline 56 & $\begin{array}{l}\text { Select the relevant people from } \\
\text { functions across the company } \\
\text { to be involved in the ecodesign } \\
\text { activities }\end{array}$ & $\begin{array}{l}\text { 108. Number of people per function engaged } \\
\text { in ecodesign activities }\end{array}$ & Number of people \\
\hline 57 & $\begin{array}{l}\text { Implement the Life Cycle } \\
\text { Thinking into the product } \\
\text { development and related } \\
\text { processes }\end{array}$ & $\begin{array}{l}\text { 109. Integration level of Life Cycle Thinking } \\
\text { into the product development and related } \\
\text { processes }\end{array}$ & Dimensionless (qualitative/scale) \\
\hline 60 & $\begin{array}{l}\text { Check the environmental } \\
\text { performance of products during } \\
\text { the gates (phase assessments) }\end{array}$ & $\begin{array}{l}\text { 110. Rate of projects (\%) with checked } \\
\text { environmental targets during the phase } \\
\text { assessments }\end{array}$ & $\begin{array}{l}\text { Percentage of projects with } \\
\text { checked environmental targets (in } \\
\text { relation to the total number of } \\
\text { projects) }\end{array}$ \\
\hline \multirow[b]{2}{*}{61} & \multirow{2}{*}{$\begin{array}{l}\text { Define and measure } \\
\text { environmental performance } \\
\text { indicators for product } \\
\text { improvement }\end{array}$} & $\begin{array}{l}\text { 111. Coverage of performance indicators for } \\
\text { different product development stages }\end{array}$ & Dimensionless (qualitative/scale) \\
\hline & & $\begin{array}{l}\text { 112. Level of alignment between performance } \\
\text { indicators and the decisions taken in product } \\
\text { development }\end{array}$ & Dimensionless (qualitative/scale) \\
\hline \multirow[t]{2}{*}{62} & \multirow{2}{*}{$\begin{array}{l}\text { Define and measure } \\
\text { performance indicators for the } \\
5 \text { of the ecodesign program }\end{array}$} & $\begin{array}{l}\text { 113. Coverage of performance indicators for } \\
\text { different projects in the ecodesign program }\end{array}$ & Dimensionless (qualitative/scale) \\
\hline & & 114. Level of alignment between the & Dimensionless (qualitative/scale) \\
\hline
\end{tabular}


Two ecodesign management practices did not have any indicators assigned, after the evaluation of experts. These practices are: practice 41 ("formulate the company environmental policy and/or strategy") and practice 58 ("measure and monitor the environmental feasibility of new product development projects"). Since our objective in this research was grounded on offering a set of meaningful and aligned performance indicators for measuring ecodesign management practices, we reviewed the existing literature, found relevant gaps and proposed new process-related performance indicators. Once these indicators were subjected to expert evaluation and then filtered accordingly, no new indicators were to be proposed without proper validation. Therefore, the lack of indicators for these two practices is a limitation of our current research methodology and is addressed in the final remarks of this paper.

Twenty-eight management practices directly consider environmental performance of products (namely practices $4,8,11,13-19,22,25,26,28-38,40$ and 60-62), from a process perspective. Usually, environmental performance assessments are primarily targeted at the impacts of a company's product portfolio and its relevant operations (e.g. supply chain and related operations). Therefore, environmental performance assessment is typically carried out at an operational level (i.e. at a product level), supported by many different and specific methods, tools and approaches. Given that the ecodesign management practices are instantiated at the strategic and tactical levels of the product development and its related processes, the focus of these 28 management practices is geared towards streamlining, in varying degrees, the use of information gained from the environmental performance assessments performed at the operational level. In this sense neither the practices' nor the indicators' purpose to prescribe the particular operationalization of the environmental performance assessment as such - an aspect which is covered by the deployment of management practices into ecodesign operational practices and into the application and customization of methods and tools (see Sections 2.2 and 2.3).

Special consideration was dedicated in suggesting units for each one of the proposed indicators as a way to further define the potential metrics to be utilized and type of data to be collected for measuring performance as well as addressing one critical gap concerning the indicators derived from literature. We highlight that these units are suggestions, and should not be seen as rigidly prescriptive. Out of the 114 proposed process-oriented performance indicators, 57 of them $(42,2 \%)$ had their units suggested as "Dimensionless (qualitative/scale)", which points to the need for developing case-specific and company-made qualitative metrics (e.g. through the use of surveys, questionnaires, focus groups, grades, qualitative judgments/evaluations etc.) or scale (e.g. based on Likert scales or psychometric test, among other methods).

As an illustrative example, consider the proposed performance indicator "degree of value chain partners' involvement in improving the environmental performance of products" for practice 25 ("consider and involve the total value chain for improving the environmental performance of products"). This is a qualitative indicator used to capture the extent to which a company's particular value chain is being directly involved in improving products' environmental performance. Depending on the company's key objectives and strategies, specific methods and measurement instruments could be developed in order to collect data: (a) a survey with value chain partners with questions based on Likert scale showing how much they agree/disagree on being involved in the improvement of the product's environmental performance; (b) a graded scale (e.g. from 0 to 10) against which key managers an decision-takers in the value chain readily assess their own involvement in such activity, with results being summarized across the actors or (c) a 5-level scale could be developed to be qualitatively evaluated and judged by higher managers and experts on the degree to which value chain partners are involved (very low involvement, low involvement, medium involvement, high involvement, very high involvement) this could be done for individual (key) partners and/or periodically evaluated over time with a view to comparing the trends.

The results of this research provides a source of knowledge for deriving, implementing and streamlining performance indicators for ecodesign management. The application, customization and adaption of the indicators must be driven, informed and revised based on the organization's strategic drivers and performance management systems. Therefore, Organizations should focus on selecting a sub-set of indicators that are meaningful and suitable to be implemented and measured. We emphasize that the implementation of the full set of indicators proposed and reported in this research is rather unrealistic and undesirable, from a business perspective.

Within this context, the performance indicators reported and proposed by this research are predominantly useful for organizations seeking higher capability levels in the application of the ecodesign management practices. In particular, the indicators can potentially support companies moving from capability level 3 to capability levels 4 or 5 , a situation in which the use of indicator is required as a way to measure, monitor and improve upon the 
application of the management practices. Figure 4 presents the overall application method prescribed by the EcoM2 (Pigosso et al., 2013), along with a schematic representation of how the performance indicators can be used in organizations. In step 1, a diagnosis of the organization's current maturity profile is performed, which defines the current capability level for each one of the 62 ecodesign management practices. Step 2 defines the desired capability level for each one of the ecodesign management practices, according to the organization's strategic drivers. This gap between the current level and the desired level is translated into roadmaps and action plans (Step 3), which will be implemented and streamlined in the organization (Step 4). For the ecodesign management practices that had their current capability level defined as either 1, 2 or 3 and desired capability level of either 4 or 5, the process-related indicators will be needed in order to monitor and control performance, leading the companies through EcoM2 steps 3 and 4.

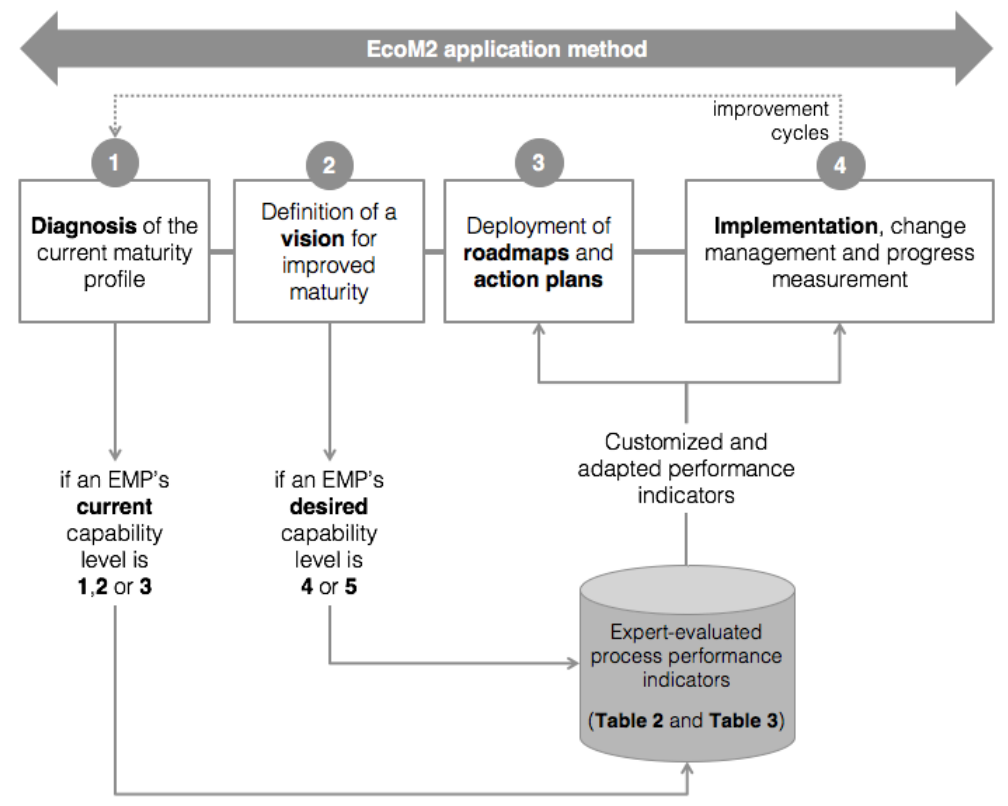

Figure 4 - Schematic illustration representing the use of the performance indicators within the context of the EcoM2 application (with overall steps 1 through 4 adapted from Pigosso et al. (2013))

As a hypothetical example, take a certain company that is actively working on improving its capabilities in ecodesign management. After performing the EcoM2 assessment and having the current capability levels for the ecodesign management practices (Step 1), the company decides that 5 practices -2 practices should be improved from the current level to the levels 4 and three other practices should be improved to capability level 5, according to the company's strategy (Step 2). Regarding the rest of the ecodesign management practices, the company decides to maintain some of them at their current capability levels, while improving others to capability levels 2 or 3 (which don't require process performance indicators). Therefore, to properly plan and carry out the capability-enhancing activities for these ten particular practices moving to capabilities 4 and 5 (Steps 3 and 4), the company has to derive process-related performance indicators. In such a context, the indicators proposed by this research for these ten particular practices play a role in supporting the company towards achieving higher capability levels in ecodesign. The indicators to be used during the capability progression should be the same in order to provide consistency and measurement alignment for the company to measure its capability development. Therefore, there is no need for changing the performance indicators for different capability levels (e.g. the indicators adopted at capability level 4 should be the same ones adopted at capability level 5). In that sense, the selection process of performance indicator does not depend on the capability at which the company is operating, but rather on other intrinsic factors, such as corporate culture, performance measurement systems in place, available information, other indicators at use etc. Table 4 consolidates the information of this hypothetical example regarding the hypothetical EMPs implemented, along with their current and desired capability levels and the process indicators that could be potentially directly applied, adapted or customized.

Table 4 - Hypothetical example of implementation of ecodesign management practices and their related process indicators use within an organizational context

\begin{tabular}{c|c|c|c|c}
\hline EMP \# & EMP description & $\begin{array}{c}\text { Current } \\
\text { capability }\end{array}$ & $\begin{array}{c}\text { Desired } \\
\text { capability }\end{array}$ & $\begin{array}{c}\text { Indicators to be directly applied, adapted or } \\
\text { customized }\end{array}$ \\
\hline
\end{tabular}




\begin{tabular}{|c|c|c|c|c|c|}
\hline & & level & level & $\begin{array}{c}\text { Table } 2 \\
\text { (Literature) }\end{array}$ & $\begin{array}{l}\text { Table } 3 \text { (Proposed and } \\
\text { Evaluated by experts) }\end{array}$ \\
\hline 10 & $\begin{array}{l}\text { Incorporate product-related } \\
\text { environmental goals into the } \\
\text { technological strategy }\end{array}$ & 2 & 5 & N/A & 19,20 and 21 \\
\hline 12 & $\begin{array}{l}\text { Collect information about applicable } \\
\text { legal issues and standards related to } \\
\text { the environmental performance of } \\
\text { products }\end{array}$ & 3 & 5 & $2,3,4,5$ and 6 & N/A \\
\hline 24 & $\begin{array}{c}\text { Incorporate the environmental aspects } \\
\text { in the identification, qualification and } \\
\text { management of suppliers }\end{array}$ & 3 & 5 & 9 and 10 & $46,47,48$ and 49 \\
\hline 28 & $\begin{array}{c}\text { Select and/or develop new } \\
\text { manufacturing and assembly } \\
\text { processes with better environmental } \\
\text { performance }\end{array}$ & 1 & 4 & 12 & $55,56,57$ and 58 \\
\hline 57 & $\begin{array}{l}\text { Implement the Life Cycle Thinking } \\
\text { into the product development and } \\
\text { related processes }\end{array}$ & 2 & 4 & N/A & 109 \\
\hline
\end{tabular}

\section{Final Remarks}

This paper presented and proposed a set of process-oriented performance indicators for measuring sustainability performance of ecodesign implementation through the use of ecodesign management practices, based on the EcoM2. The performance indicators presented in this paper were (i) retrieved from literature via the execution of a systematic literature review (Rodrigues et al., 2016a) and (ii) proposed through the definition of a rigorous and structured research methodology approach. After consolidation, 27 indicators were pulled from scientific literature and another 114 indicators were proposed. The reporting and proposal of new process-oriented performance indicators has the fundamental objective of supporting manufacturing companies while seeking for higher maturity in their ecodesign implementation and management. Even though the particular selection and prioritization of indicators was not covered by the scope of this research, this established repository of indicators are available for organizations and decision-makers to freely use, adapt and customize to their own specific context.

As emphasized in this paper, the repository of indicators can potentially support companies moving from capability level 3 to levels 4 or 5 . As the repository is not proposed to be used a fixed list of indicators, their application should be subjected to the organization's strategic drivers and context. The main academic contributions of this paper are twofold: (i) the systematization, consolidation and synthesis of knowledge regarding ecodesign performance measurement from a process-oriented perspective, which helps filling one of the fundamental gaps found in literature of ecodesign, implementation, management and performance measurement; and (ii) a proposal of new process-oriented performance indicators towards measuring specific ecodesign management practices, which can be further explored, improved, validated and adapted. Complementarily, the potential practical contributions of this paper are related to the: (i) identification and proposal of process-related performance indicators and their respective links to the application of ecodesign management practices in industrial contexts; (ii) the development of a repository of performance indicators that can be readily and easily accessed by companies; (iii) a support tool for organizations that are seeking to improve their capability level in a set of chosen ecodesign management practices, moving from formalized approaches to monitored/controlled and continuously improved approaches, therefore requiring indicators for measuring their process-level performance.

To lay out the foundation for further development in this strand of research, some current limitations of this study must be indicated. Firstly, no insights were provided in terms of how to particularly define specific metrics, scales or more granular units of measurement for each one of the indicators (for product-oriented performance indicators, see the review carried forth by Issa et al. (2015)). Secondly, the performance indicators presented and proposed are not mapped out against indicators that exist in other levels of the organization - 
neither in operational levels (e.g. product-related indicators) nor higher-level corporate levels (e.g. balancedscore card metrics and corporate performance such as overall turnover, cost structure, enterprise risk measures etc.), which might hamper the direct adoption of companies within their own (strategic) performance measurement system. Thirdly, no practical guidance for organizations on how to select, prioritize, customize or adapt the performance indicators is provided in this research.

In line with our remarks on the fact that the indicators alone are not sufficient condition for achieving higher sustainability performance, the strong alignment between indicators at the process-level with other in more strategic or operational levels is of fundamental importance towards integrating the company's effort on measuring performance. This avoids tensions in the organizations, such as the results reported in Petala et al. (2010). The authors performed an analysis on the role of product development briefs in the actual deployment of corporate sustainability. After analyzing more than 200 briefs, they found that incorporating sustainability aspects and considerations at the process level is not a sufficient condition for materializing tangible results, with a large gap between tools' development and their usage and implementation. This accounts and adds for the need of an integrated and holistic view of indicators development and, more broadly, of performance measurement systems.

Nevertheless, these limitations can be properly tackled by a number of potential lines of development for future research connected to this paper by: (i) investigating further the development and application of performance indicators for practices 41 and 58, which did not have any indicator assigned by means of applying our current method; (ii) developing practical guidelines based on action research and literature from both the academic and industrial domains - validated through case studies - on how to select, customize and adapt indicators, as well as how to define specific metrics and scales focused on ecodesign (e.g. web-based interactive solution); (iii) performing a thorough analysis of the indicators that were deemed as not aligned during the assignment and evaluation procedures with a view to identifying gaps to be filled by the proposal of new ecodesign management practices; (iv) structuring empirical research methods geared towards collecting relevant data from companies which are recognized for their superior performance in product development measurement and (v) performing an integrative research with the objective of connecting the process-level indicators of this paper with both product-level (operational) measures as well as higher-level strategic indicators, which are typically used for deriving business cases for sustainability initiatives and programs.

\section{Acknowledgments}

We express our gratitude to CNPq (National Council for Scientific and Technological Development) in Brazil for their financial support (Grant Number 200869/2014-0), to the Technical University of Denmark for their institutional support and to the STOSIP (Strategic, Tactical and Operational Implementation of Sustainability into the Innovation Process) project, based on collaborative research between Swedish and Danish institutions.

\section{References}

Acosta, C.L.., Araújo, C.S., Trabassos, L.., 2002. A review of product development performance metrics investigations with emphasis on the designer level, in: International Design Conference - Design 2002. pp. 1-6.

Amaral, D.C., Rozenfeld, H., 2007. Integrating new product development process references with maturity and change management models, in: International Conference on Engineering Design - ICED 2007.

Andreasen, M.M., Hein, L., 2000. Integrated Product Development. Institute for Product Development (IPU), Technical University of Denmark, Copenhagen.

Azevedo, S.G., Carvalho, H., Cruz Machado, V., 2011. The influence of green practices on supply chain performance: A case study approach. Transp. Res. Part E Logist. Transp. Rev. 47, 850-871. doi:10.1016/j.tre.2011.05.017

Bai, Z., Zhang, P., Liu, F., Tan, R., 2007. Product development performance measures in manufacturing firm, in: 2007 IEEE International Conference on Industrial Engineering and Engineering Management. pp. 926-929. doi:10.1109/IEEM.2007.4419327

Baumann, H., Boons, F., Bragd, a., 2002. Mapping the green product development field: Engineering, policy and business perspectives. J. Clean. Prod. 10, 409-425. doi:10.1016/S0959-6526(02)00015-X

Bevilacqua, M., Ciarapica, F.E., Giacchetta, G., 2007. Development of a sustainable product lifecycle in manufacturing firms: a case study. Int. J. Prod. Res. 45, 4073-4098. doi:10.1080/00207540701439941

Biolchini, J., Mian, P.G., Candida, A., Natali, C., 2005. Systematic Review in Software Engineering. Rio de Janeiro. doi:10.1007/978-3-540-70621-2

Blessing, L., Chakrabarti, A., 2009. DRM, a Design Research Methodology. Springer 1-411.

Boks, C., 2006. The soft side of ecodesign. J. Clean. Prod. 14, 1346-1356. doi:10.1016/j.jclepro.2005.11.015

Boks, C., Stevels, a., 2007. Essential perspectives for design for environment. Experiences from the electronics industry. Int. J. Prod. Res. 45, 4021-4039. doi:10.1080/00207540701439909

Bourne, M., Mills, J., Wilcox, M., Neely, a, Platts, K., 2000. Designing, implementing and updating performance measurement systems, International Journal of Operations \& Production Management. 
doi: $10.1108 / 01443570010330739$

Carroll, A.B., Shabana, K.M., 2010. The Business Case for Corporate Social Responsibility: A Review of Concepts, Research and Practice. Int. J. Manag. Rev. 12, 85-105. doi:10.1111/j.1468-2370.2009.00275.x

Carter, C.R., Rogers, D.S., 2008. A framework of sustainable supply chain management: moving toward new theory. Int. J. Phys. Distrib. Logist. Manag. 38, 360-387. doi:10.1108/09600030810882816

Choi, G.C.G., Ko, S.-S.K.S.-S., 2010. An integrated metric for R\&D innovation measurement. Technol. Manag. Glob. Econ. Growth (PICMET), 2010 Proc. PICMET' 10.

Costa, J.M.H., Oehmen, J., Rebentisch, E., Nightingale, D., 2014. Toward a better comprehension of Lean metrics for research and product development management. R\&D Manag. doi:10.1111/radm.12074

Cross, N., 1997. Descriptive models of creative design: application to an example. Des. Stud. 18, 427-440. doi:10.1016/S0142-694X(97)00010-0

Cross, N., Clayburn Cross, A., 1995. Observations of teamwork and social processes in design. Des. Stud. 16, $143-170$. doi:10.1016/0142-694X(94)00007-Z

Dorst, K., Cross, N., 2001. Creativity in the design process: Co-evolution of problem-solution. Des. Stud. 22, 425-437. doi:10.1016/S0142-694X(01)00009-6

Driva, H., Pawar, K.S., Menon, U., 2000. Measuring product development performance in manufacturing organisations. Int. J. Prod. Econ. 63, 147-159. doi:10.1016/S0925-5273(99)00007-9

Dües, C.M., Tan, K.H., Lim, M., 2013. Green as the new Lean: How to use Lean practices as a catalyst to greening your supply chain. J. Clean. Prod. 40, 93-100. doi:10.1016/j.jclepro.2011.12.023

Eder, W.E., Hosnedl, S., 2008. Design engineering: a manual for enhanced creativity.

Eppinger, S.D., Whitney, D.E., Smith, R.P., Gebala, D.A., 1994. A model-based method for organizing tasks in product development. Res. Eng. Des. 6, 1-13. doi:10.1007/BF01588087

Ganguly, A., Nilchiani, R., Farr, J. V., 2010. Defining a Set of Metrics to Evaluate the Potential Disruptiveness of a Technology. Eng. Manag. J. 22, 34-44. doi:10.1080/10429247.2010.11431851

Gendron, E., Pourroy, F., Carron, T., Marty, J.-C., 2012. Towards a structured approach to the definition of indicators for collaborative activities in engineering design. J. Eng. Des. 23, 195-216. doi:10.1080/09544828.2011.576334

Ghalayini, A.M., Noble, J.S., 1996. The changing basis of performance measurement. Int. J. Oper. Prod. Manag. 16, 63-80. doi:10.1108/01443579610125787

Gmelin, H., Seuring, S., 2014. Achieving sustainable new product development by integrating product life-cycle management capabilities. Int. J. Prod. Econ. 154, 166-177. doi:10.1016/j.ijpe.2014.04.023

Griffin, A., Page, A.L., 1993. An interim report on measuring product development success and failure. J. Prod. Innov. Manag. 10, 291-308. doi:10.1016/0737-6782(93)90072-X

Hajmohammad, S., Vachon, S., Klassen, R.D., Gavronski, I., 2013. Lean management and supply management: Their role in green practices and performance. J. Clean. Prod. 39, 312-320. doi:10.1016/j.jclepro.2012.07.028

Handfield, R.B., Melnyk, S. a., Calantone, R.J., Curkovic, S., 2001. Integrating environmental concerns into the design process: The gap between theory and practice. IEEE Trans. Eng. Manag. 48, 189-208. doi:10.1109/17.922478

Haque, B., Moore, M.J., 2004. Measures of performance for lean product introduction in the aerospace industry. Proc. Inst. Mech. Eng. -- Part B -- Eng. Manuf. 218, 1387-1398. doi:10.1243/0954405042323496

Hatchuel, A., Weil, B., 2003. A New Approach of Innovative Design: an Introduction To C-K theory. Int. Conf. Eng. Des. 1-15. doi:citeulike-article-id:4891368

Hauser, J.R., 2001. Metrics thermostat. J. Prod. Innov. Manag. doi:10.1111/1540-5885.1830134

Hervani, A., Helms, M., Sarkis, J., 2005. Performance measurement for green supply chain management. Benchmarking An Int. J. 12, 330-353. doi:10.1108/14635770510609015

Howard, T.J., Culley, S.J., Dekoninck, E., 2008. Describing the creative design process by the integration of engineering design and cognitive psychology literature. Des. Stud. 29, 160-180. doi:10.1016/j.destud.2008.01.001

Hsiao, S.W., Chou, J.R., 2004. A creativity-based design process for innovative product design. Int. J. Ind. Ergon. 34, 421443. doi:10.1016/j.ergon.2004.05.005

Hubka, V., Eder, W.E., 1988. Theory of Technical Systems: A Total Concept Theory for Engineering Design. SpringerVerlag.

Humphreys, P., Huang, G., Cadden, T., McIvor, R., 2007. Integrating design metrics within the early supplier selection process. J. Purch. Supply Manag. 13, 42-52. doi:10.1016/j.pursup.2007.03.006

ISO, 2011. ISO 14.006 - Environmental management systems: guidelines for incorporating ecodesign.

Issa, I.I., Pigosso, D.C.A., McAloone, T.C., Rozenfeld, H., 2015. Leading product-related environmental performance indicators: a selection guide and database. J. Clean. Prod. doi:10.1016/j.jclepro.2015.06.088

Keeble, J.J., Topiol, S., Berkeley, S., 2003. Using indicators to measure sustainability performance at a corporate and project level. J. Bus. Ethics 44, 149-158. doi:10.1023/A:1023343614973

Kennerley, M., Neely, A., 2002. A framework of the factors affecting the evolution of performance measurement systems. Int. J. Oper. Prod. Manag. 22, 1222-1245. doi:10.1108/01443570210450293

Keong Choong, K., 2013. Understanding the features of performance measurement system: a literature review. Meas. Bus. Excell. 17, 102-121. doi:10.1108/MBE-05-2012-0031

Kim, H.-B., Kim, Y.-S., 2015. Performance indices for quantitative measurement of R\&amp;D results in private construction companies. KSCE J. Civ. Eng. 19, 814-830. doi:10.1007/s12205-015-2369-6

Knight, P., Jenkins, J.O., 2009. Adopting and applying eco-design techniques: a practitioners perspective. J. Clean. Prod. 17, 549-558. doi:10.1016/j.jclepro.2008.10.002

Kulatunga, U., Amaratunga, D., Haigh, R., 2011. Structured approach to measure performance in construction research and development. Int. J. Product. Perform. Manag. 60, 289-310. doi:10.1108/17410401111112005

Lacey, R., Kennett-Hensel, P.A., Manolis, C., 2015. Is corporate social responsibility a motivator or hygiene factor? Insights 
into its bivalent nature. J. Acad. Mark. Sci. 43, 315-332. doi:10.1007/s11747-014-0390-9

Lin, C.C., Luh, D.B., 2009. A vision-oriented approach for innovative product design. Adv. Eng. Informatics 23, 191-200. doi:10.1016/j.aei.2008.10.005

Lozano, R., 2012. Towards better embedding sustainability into companies' systems: an analysis of voluntary corporate initiatives. J. Clean. Prod. 25, 14-26. doi:10.1016/j.jclepro.2011.11.060

Lozano, R., Carpenter, A., Huisingh, D., 2015. A review of "theories of the firm" and their contributions to Corporate Sustainability. J. Clean. Prod. 106, 430-442. doi:10.1016/j.jclepro.2014.05.007

Luiz, J.V.R., Jugend, D., Jabbour, C.J.C., Luiz, O.R., de Souza, F.B., 2016. Ecodesign field of research throughout the world: mapping the territory by using an evolutionary lens. Scientometrics 1-19. doi:10.1007/s11192-016-2043-x

Luz, L.M., de Francisco, A.C., Piekarski, C.M., 2015. Proposed model for assessing the contribution of the indicators obtained from the analysis of life-cycle inventory to the generation of industry innovation. J. Clean. Prod. 96, 339348. doi:10.1016/j.jclepro.2014.03.004

McAloone, T., 1998. Industry Experiences of Environmentally Conscious Design Integration: an Exploratory Study. Cranfield University.

McAloone, T., Bey, N., 2009. Environmental improvement through product development: A guide.

Medori, D. \& Steeple, D., 2000. A framework for auditing and enhancing performance measurement systems. Int. J. Oper. Prod. Manag. 20(5), 520-33.

Nappi, V., Rozenfeld, H., 2015. The Incorporation of Sustainability Indicators into a Performance Measurement System. Procedia CIRP 26, 7-12. doi:10.1016/j.procir.2014.07.114

Nappi, V., Rozenfeld, H., 2013. Sustainability Performance Indicators for Product Lifecycle Management, in: Proceedings of the 22th International Confgress of Mechanical Engineering (COBEM). ABCM, Ribeirão Preto, pp. 4071-4082.

Neely, A., 2005. The evolution of performance measurement research: Developments in the last decade and a research agenda for the next. Int. J. Oper. Prod. Manag. 25, 1264-1277. doi:10.1108/01443570510633648

Nielsen, P.., Wenzel, H., 2002. Integration of environmental aspects in product development: a stepwise procedure based on quantitative life cycle assessment. J. Clean. Prod. 10, 247-257. doi:10.1016/S0959-6526(01)00038-5

Pahl, G., Beitz, W., Feldhusen, J., Grote, K.H., 2007. Engineering design: a systematic approach, Third Edit. ed. Springer. doi:10.1007/978-1-84628-319-2

Petala, E., Wever, R., Dutilh, C., Brezet, H., 2010. The role of new product development briefs in implementing sustainability: A case study. J. Eng. Technol. Manag. 27, 172-182. doi:10.1016/j.jengtecman.2010.06.004

Pigosso, D.C.., McAloone, T.C., Rozenfeld, H., 2015. Characterization of the State-of-the-art and Identification of Main Trends for Ecodesign Tools and Methods: Classifying Three Decades of Research and Implementation. J. Indian Inst. Sci. 95, 405-427.

Pigosso, D.C.., McAloone, T.C., Rozenfeld, H., 2014. Systematization of best practices for ecodesign implementation, in: International Design Conference - Design 2014. Dubrovinik, Croatia, pp. 1651-1662.

Pigosso, D.C.A., 2012. Ecodesign Maturity Model: a framework to support companies in the selection and implementation of ecodesign practices. Bibl. Digit. USP. Universidade de São Paulo.

Pigosso, D.C.A., Rozenfeld, H., McAloone, T.C., 2013. Ecodesign maturity model: A management framework to support ecodesign implementation into manufacturing companies. J. Clean. Prod. 59, 160-173. doi:10.1016/j.jclepro.2013.06.040

Pigosso, D.C. a, Rozenfeld, H., Seliger, G., 2011. Ecodesign Maturity Model : criteria for methods and tools classification. Adv. Sustain. Manuf. 241-245. doi:10.1007/978-3-642-20183-7_35

Plouffe, S., Lanoie, P., Berneman, C., Vernier, M.F., 2011. Economic benefits tied to ecodesign. J. Clean. Prod. 19, 573579. doi:10.1016/j.jclepro.2010.12.003

Porter, M.E., Kramer, M.R., 2006. Strategy \& society: The link between competitive advantage and corporate social responsibility. Harv. Bus. Rev. 84, 78-92. doi:10.1287/mnsc.1090.1070

Rochlin, S., Bliss, R., Jordan, S., Kiser, C.Y., 2015. Project ROI: defining the competitive and financial advantages of corporate responsibility and sustainability.

Rodrigues, V.P., Pigosso, D.C.A., McAloone, T.C., 2016a. Process-related key performance indicators for measuring sustainability performance of ecodesign implementation into product development. J. Clean. Prod. 139, 416-428. doi:10.1016/j.jclepro.2016.08.046

Rodrigues, V.P., Pigosso, D.C.A., McAloone, T.C., 2016b. Process-oriented performance indicators for measuring ecodesign management practices, in: International Design Conference - DESIGN 2016. Dubrovinik, Croatia, pp. 443452.

Rozenfeld, H., 2007. Reference model for managing product development, in: Seliger, G. (Ed.), Sustainability in Manufacturing: Recovery of Resources in Product and Material Cycles. Springer, pp. 193-206.

Rozenfeld, H., Forcellini, F.A., Amaral, D.C., Toledo, J.C., Silva, S.L., Alliprandini, D.H., Scalice, R.K., 2006. Gestão do desenvolvimento de produtos: uma referência para a melhoria do processo, 1st ed. Saraiva.

Sarkis, J., 2003. A strategic decision framework for green supply chain management. J. Clean. Prod. 11, 397-409. doi:10.1016/S0959-6526(02)00062-8

Seuring, S., Müller, M., 2008. From a literature review to a conceptual framework for sustainable supply chain management. J. Clean. Prod. 16, 1699-1710. doi:10.1016/j.jclepro.2008.04.020

Soylu, K., Dumville, J.C., 2011. Design for environment: The greening of product and supply chain. Marit. Econ. Logist. 13, 29-43. doi:10.1057/mel.2010.19

Suh, N.P., 1998. Axiomatic Design Theory for Systems. Res. Eng. Des. 10, 189-209. doi:10.1007/s001639870001

Tjalve, E., 2003. Systematic Design of Industrial Products. Institute for Product Development (IPU), Technical University of Denmark, Copenhagen.

Tolonen, A., Shahmarichatghieh, M., Harkonen, J., Haapasalo, H., 2015. Product portfolio management - Targets and key 


\section{ACCEPTED MANUSCRIPT}

performance indicators for product portfolio renewal over life cycle. Int. J. Prod. Econ. doi:10.1016/j.ijpe.2015.05.034 Ulrich, K.T., Eppinger, S.D., 2008. Product Design and Development, New York.

United Nations, 2015. Global Sustainable Development Report.

Ussui, P.R.S., Borsato, M., 2013. Sustainability indicators for the product development process in the auto parts industry. 20th ISPE Int. Conf. Concurr. Eng. CE 2013 - Proc. 481-493. doi:10.3233/978-1-61499-302-5-481

Vanek, F., Jackson, P., Grzybowski, R., 2008. Model Based Systems Engineering with Department of Defense Architectural Framework. Syst. Eng. 14, 305-326. doi:10.1002/sys

Verhaegen, P.A., Vandevenne, D., Peeters, J., Duflou, J.R., 2013. Refinements to the variety metric for idea evaluation. Des. Stud. 34, 243-263. doi:10.1016/j.destud.2012.08.003

Vezzoli, C., Manzini, E., 2008. Design for environmental sustainability, Design for Environmental Sustainability. doi:10.1007/978-1-84800-163-3

WCED, 1987. Our Common Future, Oxford paperbacks. doi:10.2307/2621529

Yim, R., Castaneda, J., Doolen, T., Tumer, I., Malak, R., 2015a. Managing risk in projects. Proj. Manag. J. 46, 63-75. doi:10.1002/pmj

Yim, R., Castaneda, J., Doolen, T., Tumer, I., Malak, R., 2015b. A study of the impact of project classification on project risk indicators. Int. J. Proj. Manag. 33, 863-876. doi:10.1016/j.ijproman.2014.10.005

Zhu, Q., Sarkis, J., Lai, K., 2008. Confirmation of a Measurement Model for Green Supply Chain Management Practices Implementation. Int. J. Prod. Econ. 111, 261-273. doi:10.1016/j.ijpe.2006.11.029 